\title{
On the wintertime low bias of Northern Hemisphere carbon monoxide found in global model simulations
}

\author{
O. Stein ${ }^{1}$, M. G. Schultz ${ }^{1}$, I. Bouarar ${ }^{2, *}$, H. Clark ${ }^{3,4, * *}$, V. Huijnen ${ }^{5}$, A. Gaudel ${ }^{3,4}$, M. George ${ }^{2}$, and C. Clerbaux ${ }^{2}$ \\ ${ }^{1}$ Forschungszentrum Jülich, IEK-8 (Troposphere), Jülich, Germany \\ ${ }^{2}$ UPMC Univ. Paris 06; Université Versailles St-Quentin; CNRS/INSU, LATMOS-IPSL, Paris, France \\ ${ }^{3}$ Université de Toulouse, UPS, LA (Laboratoire d'Aérologie), Toulouse, France \\ ${ }^{4}$ CNRS, LA (Laboratoire d'Aérologie), UMR5560, Toulouse, France \\ ${ }^{5}$ KNMI, De Bilt, the Netherlands \\ *now at: Max Planck Institute for Meteorology, Hamburg, Germany \\ ** now at: CERFACS and CNRS, URA1875, Toulouse, France
}

Correspondence to: O. Stein (o.stein@fz-juelich.de)

Received: 17 October 2013 - Published in Atmos. Chem. Phys. Discuss.: 6 January 2014

Revised: 7 July 2014 - Accepted: 29 July 2014 - Published: 9 September 2014

\begin{abstract}
Despite the developments in the global modelling of chemistry and of the parameterization of the physical processes, carbon monoxide $(\mathrm{CO})$ concentrations remain underestimated during Northern Hemisphere (NH) winter by most state-of-the-art chemistry transport models. The consequential model bias can in principle originate from either an underestimation of $\mathrm{CO}$ sources or an overestimation of its sinks. We address both the role of surface sources and sinks with a series of MOZART (Model for Ozone And Related Tracers) model sensitivity studies for the year 2008 and compare our results to observational data from ground-based stations, satellite observations, and vertical profiles from measurements on passenger aircraft. In our base case simulation using MACCity (Monitoring Atmospheric Composition and Climate project) anthropogenic emissions, the near-surface $\mathrm{CO}$ mixing ratios are underestimated in the Northern Hemisphere by more than $20 \mathrm{ppb}$ from December to April, with the largest bias of up to 75 ppb over Europe in January. An increase in global biomass burning or biogenic emissions of $\mathrm{CO}$ or volatile organic compounds (VOCs) is not able to reduce the annual course of the model bias and yields concentrations over the Southern Hemisphere which are too high. Raising global annual anthropogenic emissions with a simple scaling factor results in overestimations of surface mixing ratios in most regions all year round. Instead, our results indicate that anthropogenic $\mathrm{CO}$ and, possibly, VOC emissions in the MACCity inventory are too low for the industrialized
\end{abstract}

countries only during winter and spring. Reasonable agreement with observations can only be achieved if the $\mathrm{CO}$ emissions are adjusted seasonally with regionally varying scaling factors. A part of the model bias could also be eliminated by exchanging the original resistance-type dry deposition scheme with a parameterization for $\mathrm{CO}$ uptake by oxidation from soil bacteria and microbes, which reduces the boreal winter dry deposition fluxes. The best match to surface observations, satellite retrievals, and aircraft observations was achieved when the modified dry deposition scheme was combined with increased wintertime road traffic emissions over Europe and North America (factors up to 4.5 and 2, respectively). One reason for the apparent underestimation of emissions may be an exaggerated downward trend in the Representative Concentration Pathway (RCP) 8.5 scenario in these regions between 2000 and 2010, as this scenario was used to extrapolate the MACCity emissions from their base year 2000. This factor is potentially amplified by a lack of knowledge about the seasonality of emissions. A methane lifetime of $9.7 \mathrm{yr}$ for our basic model and $9.8 \mathrm{yr}$ for the optimized simulation agrees well with current estimates of global $\mathrm{OH}$, but we cannot fully exclude a potential effect from errors in the geographical and seasonal distribution of $\mathrm{OH}$ concentrations on the modelled $\mathrm{CO}$. 


\section{Introduction}

Carbon monoxide (CO) is a product of incomplete combustion and is also produced from oxidation of volatile organic compounds (VOCs) in the atmosphere. It is of interest as an indirect greenhouse gas and acts as a major sink for the $\mathrm{OH}$ radical. The resulting inverse relationship between $\mathrm{CO}$ and $\mathrm{OH}$ is a reason for its important indirect control function on the global atmospheric chemical composition (Novelli et al., 1998). CO is also a precursor for tropospheric ozone and thus affects regional air quality.

Due to its mean tropospheric lifetime of about 2 months, $\mathrm{CO}$ can be transported globally and is often used as a tracer for long-range pollution transport (e.g. Li et al., 2002; Liu et al., 2003; Duncan and Bey, 2004; Law and Stohl, 2007; Shindell et al., 2008; Drori et al., 2012; Cristofanelli et al., 2013). Tropospheric CO builds up over the Northern Hemisphere $(\mathrm{NH})$ during wintertime, when emissions are high and photochemical activity is low. The surface $\mathrm{CO}$ mixing ratios peak around March, with typical values measured at background stations of around $150 \mathrm{ppb}$. Above and downwind of strongly polluted areas in East Asia, North America, or Europe, wintertime mixing ratios are significantly higher. Values above $1000 \mathrm{ppb}$ have been reported over eastern China (e.g. Wang et al., 2004; Gao et al., 2005). Summertime mixing ratios are significantly lower, with $\mathrm{NH}$ background values going down to $100 \mathrm{ppb}$ due to the faster photochemical depletion of $\mathrm{CO}$. In some regions, the highest mixing ratios are measured from August to October, largely influenced by emissions from biomass burning (Worden et al., 2013). Tropical and Southern Hemisphere (SH) mixing ratios are generally lower (values as low as 35-40 ppb have been observed in remote areas) due to the lower amount of anthropogenic emissions and the large ocean surface (Novelli et al., 1998; Duncan et al., 2007).

The main sources of $\mathrm{CO}$ are from anthropogenic and natural direct emissions and from the oxidation of methane and other VOCs. Dominant emissions are from road traffic, fossil fuel and biomass burning together with smaller contributions from vegetation and the oceans. Automobile traffic contributes about $85 \%$ of the 2008 emissions of CO from fossil fuels in the USA (http://www.epa.gov/air/emissions/) but only $26 \%$ of the 2011 anthropogenic emissions for the European Union (EEA, 2013). In developing countries, residential burning of coal and biomass constitutes a large fraction of $\mathrm{CO}$ emissions. Reaction with $\mathrm{OH}$ radicals acts as the major CO sink (Prather et al., 2001; Duncan et al., 2007), while deposition in soils contributes about $10-15 \%$ to the global atmospheric CO losses (Conrad, 1996; Sanhueza et al., 1998; King, 1999). A schematic overview of the global $\mathrm{CO}$ budget is given in Fig. 1 .

In spite of more than 15 years of research, there are still considerable uncertainties about the global budget of $\mathrm{CO}$ for both its sources and sinks. Table 1 lists anthropogenic $\mathrm{CO}$ emission totals from recent global and regional emission

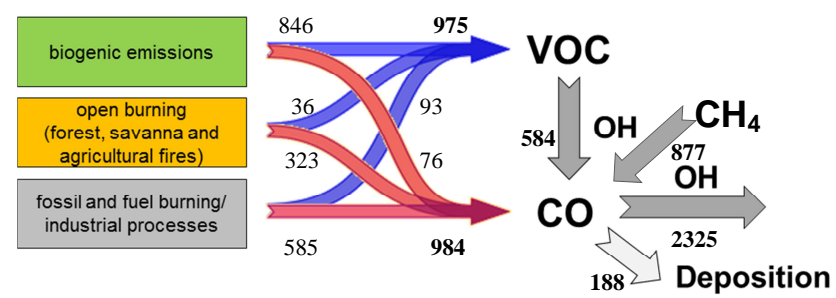

Figure 1. The global CO budget: sources and sinks. Numbers are in teragrams per year as estimated from this study using MACCity/MEGAN/GFAS emissions for the year 2008.

inventories. The inventories report global anthropogenic emissions of 494-611 $\mathrm{Tg} \mathrm{CO} \mathrm{yr}^{-1}$ for the period 2000-2005. Emission reductions in the industrialized countries since the late 1990s (e.g. EEA, 2013) have been largely compensated by an increase in the developing countries, particularly in Asia (Kurokawa et al., 2013).

The second-most-important direct $\mathrm{CO}$ emission source is biomass burning. Observations of burnt areas, active fires and fire radiative power from various satellite instruments have been used to constrain these emissions on the global scale. Global and regional totals for the year 2005 from the most recent emission inventories - GFEDv2 (Global Fire Emissions Database, version 2; van der Werf et al., 2006), GFEDv3 (van der Werf et al., 2010), and GFASv1 (Global Fire Assimilation System; Kaiser et al., 2012) - are displayed in Table 2. Note the large differences in continental-scale emissions between the inventories and the large interannual variability in the data sets. Biogenic emissions of $\mathrm{CO}$ generally contribute less than $10 \%$ to the global total emissions. Estimates derived from MEGANv2 (Guenther et al., 2006) and the totals from the MEGAN-MACC (Model of Emissions of Gases and Aerosols from Nature-Monitoring Atmospheric Composition and Climate) inventory (Sindelarova et al., 2014) are also listed in Table 2.

Global in situ production of $\mathrm{CO}$ from methane oxidation is estimated at about $800 \mathrm{Tg} \mathrm{yr}^{-1}$ (Prather et al., 2001). The ensemble model simulations performed for the year 2000 in Shindell et al. (2006) yielded 578 to $999 \mathrm{Tg} \mathrm{yr}^{-1}$ of $\mathrm{CO}$ from this source, with a multimodel mean of $766 \mathrm{Tg} \mathrm{yr}^{-1}$. Since methane had been prescribed as a uniform mixing ratio at the surface for all models, this variability reflects the differences in the $\mathrm{OH}$ radical distribution among the models. The chemical production of $\mathrm{CO}$ from oxidation of other VOCs is even more uncertain. These emissions are dominated by biogenic sources, notably from isoprene, methanol, and terpenes. While Prather et al. (2001) reported $430 \mathrm{Tg} \mathrm{yr}^{-1}$ of CO, Duncan et al. (2007) calculated a range of 501-542 $\mathrm{Tg} \mathrm{yr}^{-1}$ for the period 1988-1997 with the GEOS-Chem model. The global simulations reported by Shindell et al. (2006) yielded 547-1198 $\mathrm{Tg} \mathrm{yr}^{-1}$, with a multimodel mean of $730 \mathrm{Tg} \mathrm{yr}^{-1}$, pointing to large differences 
Table 1. Global and regional $\mathrm{CO}$ anthropogenic emission totals from recent bottom-up inventories in teragrams per year. All data except from EPA and Environmental Canada are available online from the Emissions of atmospheric Compounds \& Compilation of Ancillary Data (ECCAD) database (http://eccad.sedoo.fr/).

\begin{tabular}{|c|c|c|c|c|c|c|c|c|}
\hline & ACCMIP $^{\mathrm{a}}$ & RETRO/REAS ${ }^{\mathrm{b}}$ & MACCity $^{\mathrm{c}}$ & EDGARv4.2 ${ }^{\mathrm{d}}$ & EMEP $^{\mathrm{e}}$ & TNO-MACC & EPA + Env. Canada ${ }^{\mathrm{g}}$ & REASv $1^{\mathrm{h}}$ \\
\hline Release year & 2010 & 2008 & 2010 & 2011 & 2007 & 2009 & 2013 & 2007 \\
\hline Reference year & 2000 & $2000 / 2003$ & $2005 / 2008$ & 2005 & 2005 & 2005 & 2005 & $2003 / 2005$ \\
\hline Global & 611 & 577 & $583 / 586$ & 494 & & & & \\
\hline Europe & 59 & 49 & $49 / 43$ & 46 & 51 & 50 & & \\
\hline North America & 118 & 70 & $70 / 62$ & 82 & & & 82 & \\
\hline Asia & 320 & 362 & $341 / 352$ & 256 & & & & $338 / 345$ \\
\hline - China & 121 & 158 & $138 / 146$ & 90 & & & & $158 / 162$ \\
\hline Africa & 83 & 69 & $95 / 101$ & 61 & & & & \\
\hline South America & 22 & 24 & $24 / 24$ & 46 & & & & \\
\hline Oceania & 6 & 3 & $3 / 3$ & 4 & & & & \\
\hline
\end{tabular}

${ }^{\mathrm{a}}$ Lamarque et al. (2010)

b Schultz et al. (2007)

$\mathrm{c}$ Granier et al. (2011)

d Janssens-Maenhout et al. (2011)

e Amann et al. (2005)

f Denier van der Gon et al. (2011)

$\mathrm{g}$ http://www.epa.gov/ttn/chief/eiinformation.html; http://www.ec.gc.ca/indicateurs-indicators/

${ }^{\mathrm{h}}$ Ohara et al. (2007)

Table 2. Global and regional $2005 \mathrm{CO}$ emission totals from recent biomass burning and biogenic emission inventories in teragrams per year. Data are available from the ECCAD database.

\begin{tabular}{lrrr|rr}
\hline & \multicolumn{3}{c|}{ Biomass burning } & \multicolumn{2}{c}{ Biogenic } \\
\cline { 2 - 6 } & GFEDv2 & GFEDv3 & GFASv1 & MEGANv2 & MEGAN-MACC \\
\hline Release year & 2006 & 2010 & 2012 & 2009 & 2012 \\
Reference year & 2005 & 2008 & 2008 & 2000 & 2008 \\
Global & 416 & 277 & 325 & 76 & 84 \\
global range & $369-599^{\mathrm{a}}$ & $252-595^{\mathrm{b}}$ & $305-404^{\mathrm{c}}$ & & $83-93^{\mathrm{d}}$ \\
Europe & 19 & 38 & 66 & 5 & 4 \\
North America & 19 & 16 & 20 & 9 & 7 \\
Asia & 82 & 22 & 41 & 18 & 15 \\
Africa & 183 & 152 & 140 & 18 & 27 \\
South America & 101 & 37 & 48 & 19 & 8 \\
Oceania & 11 & 11 & 12 & 7 & \\
\hline a 1997-2005 & & & & & \\
b 1997-2010 & & & & & \\
c 2003-2011 & & & & & \\
d 2000-2010 & & & & & \\
\end{tabular}

among the $\mathrm{VOC}$ emission schemes and again the $\mathrm{OH}$ distribution in the various models.

The global annual loss rate of $\mathrm{CO}$ by oxidation with $\mathrm{OH}$ roughly balances the total sources and is estimated as 1500-2700 $\mathrm{Tg} \mathrm{yr}^{-1}$ (Prather et al., 2001). Other model studies derived a range of $2231-2618 \mathrm{Tg} \mathrm{yr}^{-1}$ (Duncan et al., 2007, and references therein). This important CO sink depends on an accurate calculation of the global $\mathrm{OH}$ distribution, which itself cannot be measured directly. Instead, the global annual average CO loss term can be quantified by the methane lifetime. Prinn et al. (2005) estimated a methane lifetime due to tropospheric $\mathrm{OH}$ loss of 10.2 (9.511.1) years, while Prather et al. (2012) determined a presentday methane lifetime of $11.2( \pm 1.3) \mathrm{yr}$ from a systematic exploration of known greenhouse gas budgets and its uncertainties. Shindell et al. (2006) calculated a multimodel mean of $9.7( \pm 1.7) \mathrm{yr}$, which is in line with results from the Atmospheric Chemistry and Climate Model Intercomparison Project (ACCMIP) (Voulgarakis et al., 2013; Naik et al., 2013).

The only other known loss process of $\mathrm{CO}$ besides reaction with $\mathrm{OH}$ is dry deposition. Reported CO dry deposition velocities for vegetated surfaces based on measurements are relatively low compared with other substances and reach from 0 to $0.004 \mathrm{~m} \mathrm{~s}^{-1}$, with most values below $0.001 \mathrm{~m} \mathrm{~s}^{-1}$ (King, 1999; Castellanos et al., 2011, and references therein). Prather et al. (2001) reported the global sink to be as high as $250-640 \mathrm{Tg} \mathrm{yr}^{-1}$. King (1999) confirmed the 190 $580 \mathrm{Tg} \mathrm{yr}^{-1}$ range proposed by Conrad and Seiler (1985) derived from empirical approaches but with a higher probability 
for lower values. Based on a constant dry deposition velocity of $0.03 \mathrm{~cm} \mathrm{~s}^{-1}$, Sanhueza et al. (1998) estimated the global gross uptake to be 115 to $230 \mathrm{Tg} \mathrm{yr}^{-1}$. Bergamaschi et al. (2000) derived annual deposition fluxes of about $300 \mathrm{Tg} \mathrm{yr}^{-1}$ using the same constant deposition velocity, but setting the deposition velocity to zero in deserts and areas with monthly mean temperatures below $0{ }^{\circ} \mathrm{C}$.

Little focus has been placed so far on the role of CO dry deposition in global modelling. Most models apply a dry deposition scheme based on the resistance model of Wesely (1989). Often, the resistance values for $\mathrm{O}_{3}$ and $\mathrm{SO}_{2}$ are scaled to derive parameterizations for $\mathrm{CO}$ and other substances (Wesely and Hicks, 2000). Such schemes give quite variable dry deposition velocities (Stevenson et al., 2006), but there has not been a systematic intercomparison among the different models yet except for the study of Dentener et al. (2006), where the focus was on wet deposition of $\mathrm{NO}_{\mathrm{x}}$ and $\mathrm{SO}_{2}$. Other models assume that the $\mathrm{CO}$ dry deposition losses are to some degree counterbalanced by the plant emissions (e.g. Arellano et al., 2004, 2006; Duncan et al., 2007) and therefore neglect both the soil sink and the biogenic emissions. Only a few models (Emmons et al., 2010; Lamarque et al., 2012) have extended their dry deposition scheme with a parameterization for $\mathrm{CO}$ and $\mathrm{H}_{2}$ uptake by oxidation from soil bacteria and microbes following the work of Sanderson et al. (2003), which itself was based on extensive measurements from Yonemura et al. (2000). In this case, $\mathrm{CO}$ and $\mathrm{H}_{2}$ deposition velocities depend on the soil moisture content of the specific land cover type and on snow cover. Ehhalt and Rohrer (2009) evaluated existing parameterizations of $\mathrm{H}_{2}$ uptake by soils. They found that none of the existing model studies accounted fully for the essential dependencies of dry deposition velocities on snow cover, soil moisture, and vegetation type that are found in the field experiments, the only exception being the work from Sanderson et al. (2003).

As there have been only modestly decreasing trends observed in the concentrations of CO after the 1990s (FortemsCheiney et al., 2011; Worden et al., 2013), the sources and sinks of CO must be approximately in balance, except for some seasonal and interannual variations in the CO budget (Duncan and Logan, 2008). The few published estimates of the atmospheric CO burden date back to the 1990s, with 365-410 Tg (Granier et al., 1996), 380-470 Tg (Reichle and Connors, 1999), and $360 \mathrm{Tg}$ (Prather et al., 2001).

For a long time, global models have underestimated carbon monoxide mixing ratios in the $\mathrm{NH}$ as is comprehensively shown in the Task Force Hemispheric Transport of Air Pollution (TFHTAP) model intercomparison study by Shindell et al. (2006). Their multimodel mean from 26 global models exhibited large underestimates of $\mathrm{NH}$ extratropical $\mathrm{CO}$, particularly during winter and spring as compared to NOAA GMD (National Oceanic and Atmospheric Administration Global Monitoring Division) station measurements. Such a bias is still existent in more recent model studies; cf. Elguindi et al. (2010), Huijnen et al. (2010), Fisher et al. (2010), and Williams et al. (2013).

With the growing availability of atmospheric $\mathrm{CO}$ observation data from surface and in situ observations as well as from satellites, a number of global model inversions have been performed to derive optimized $\mathrm{CO}$ sources from these observations (Bergamaschi et al., 2000; Pétron et al., 2002, 2004; Arellano et al., 2004, 2006; Müller and Stavrakou, 2005; Duncan et al., 2007; Pison et al., 2009; Kopacz et al., 2010; Fortems-Cheiney et al., 2011; Hooghiemstra et al., 2011, 2012; Miyazaki et al., 2012). Most of these studies found a significant underestimation of $\mathrm{CO}$ sources in their a priori estimates and assigned those to missing emissions in the current inventories. The additional total $\mathrm{CO}$ sources needed were as high as $392 \mathrm{Tg} \mathrm{yr}^{-1}$ (FortemsCheiney et al., 2011), $492 \mathrm{Tg} \mathrm{yr}^{-1}$ (Kopacz et al., 2010) and $530 \mathrm{Tg} \mathrm{yr}^{-1}$ (Hooghiemstra et al., 2012, including indirect $\mathrm{CO}$ sources from VOC oxidation). From both forward and inverse model studies, a major part of the missing source was attributed to NH anthropogenic emissions (e.g. Shindell et al., 2006; Müller and Stavrakou, 2005; Kopacz et al., 2010; Hooghiemstra et al., 2012).

In the MACC project, the technique of variational data assimilation has been employed to perform a global reanalysis simulation for the years 2003-2010 (Inness et al., 2013), including a detailed chemistry scheme from the global chemistry transport model MOZART-3 (Model for Ozone And Related Tracers, version 3; Kinnison et al., 2007; Flemming et al., 2009). Total and partial columns as well as vertically resolved observations of $\mathrm{O}_{3}, \mathrm{CO}$, and $\mathrm{NO}_{2}$ from multiple satellite sensors have been assimilated (Stein et al., 2012). A MOZART control simulation without data assimilation exhibited negative biases of $\mathrm{NH} \mathrm{CO}$ mixing ratios as large as $35 \%$ on average in the lower troposphere as compared to vertical profile measurements at airports north of $30^{\circ} \mathrm{N}$ (A. Inness, personal communication, 2013). This bias could be reduced by the assimilation of CO total columns. Directly at the surface however, where the influence of the surface fluxes is most important, the assimilation of $\mathrm{CO}$ satellite total columns had only a small effect on the modelled mixing ratios. The remaining model bias in the lower troposphere was attributed to an underestimation of emission fluxes in the MACCity inventory (Inness et al., 2013).

Motivated by the discrepancy that is often found between simulated and observed $\mathrm{CO}$ concentrations, particularly near the surface in the $\mathrm{NH}$ during winter, we have conducted a set of sensitivity simulations to shed further light on the uncertainties in the global CO budget. Specifically, this study addresses the following questions:

1. To what extent could direct or precursor CO emissions be underestimated in current global inventories? 
2. What is the impact of uncertainties in the dry deposition parameterization of $\mathrm{CO}$ on the global burden and surface mixing ratios of $\mathrm{CO}$ ?

3. To what extent are the modelled $\mathrm{CO}$ concentrations controlled by global levels and distribution of the $\mathrm{OH}$ radical?

Based on a series of global chemistry transport model simulations we analyse the response of tropospheric $\mathrm{CO}$ concentrations to different sets of trace gas surface boundary conditions spanning the uncertainties in our current knowledge about $\mathrm{CO}$ emission and deposition.

The outline of the paper is as follows: in Sect. 2 we will describe the model setup for our simulations. Section 3 summarizes the data sets used for evaluation, and Sect. 4 describes the model sensitivity simulations. The results from the sensitivity studies on surface emissions and dry deposition are presented in Sect. 5, followed by our conclusions in Sect. 6 .

\section{Model description}

\subsection{MOZART}

The version of MOZART as employed in this work is based on the MOZART-3 model code (Kinnison et al., 2007), which itself is an extension of the tropospheric chemical transport model MOZART-2 (Horowitz et al., 2003) to the stratosphere and mesosphere. Some features have been added from MOZART-4 (Emmons et al., 2010): most notably a reasonably detailed isoprene degradation scheme as described in Pfister et al. (2008) and a description of $\mathrm{SO}_{\mathrm{x}}$ and the nitrogen cycle. Other improvements have been introduced with the model version used in this paper, including an update of chemical rate constants as well as improvements in the photolysis look-up-table approach and the parameterization of polar stratospheric clouds.

The MOZART global model simulations presented here are driven by meteorological fields from the ECMWF (European Centre for Medium-Range Weather Forecasts) ERA Interim reanalysis (Dee et al., 2011) and run at a horizontal resolution of $1.875^{\circ} \times 1.875^{\circ}$ with 60 hybrid vertical levels from the surface to the mesosphere and a time step of $15 \mathrm{~min}$. The MOZART chemical mechanism consists of 115 species, 71 photolysis reactions, 223 gas phase reactions, and 21 heterogeneous reactions. Reaction rates have been updated to Sander et al. (2006) wherever applicable. Output for tracer mixing ratios and other model fields are available with a temporal resolution of $3 \mathrm{~h}$.

\subsection{Surface boundary conditions}

A new inventory of global anthropogenic emissions for trace gases and aerosols has been developed in the MACC and CityZen projects (Granier et al., 2011), which provides up-to-date estimates for use in global model simulations (MACCity; Table 1). These emission estimates are based on the ACCMIP emissions for the year 2000 (Lamarque et al., 2010). The 2000-2010 MACCity emissions were obtained by using the 2005 and 2010 emissions from the future scenario RCP8.5 (Representative Concentration Pathway): a linear interpolation was applied to obtain the yearly MACCity emissions, here for the year 2008. RCP8.5 corresponds to a radiative forcing of $8.5 \mathrm{~W} \mathrm{~m}^{-2}$ in the year 2100 given the respective emissions (Moss et al., 2010; van Vuuren et al., 2011; Riahi et al., 2011). A source-specific seasonality developed for the for the RETRO (REanalysis of the TROpospheric chemical composition over the past 40 years) project (Schultz et al., 2007; http://retro.enes.org/) was applied to the emissions. MACCity also includes ship emissions based on Eyring et al. (2010). Natural emissions are not included in the MACCity inventory. Here they are based on MEGANv2 (Table 2), and other natural emissions were taken from the POET (Predicting the Impacts of e-Economy on Transport) project (Granier et al., 2005) and from the Global Emissions Initiative (GEIA). These emissions are meant to be representative of the year 2000. The MACCity anthropogenic emissions and the additional natural emissions are used as reference emissions for our MOZART 2008 sensitivity simulations, which will be presented in the Sect. 4 and have also been used in the MACC reanalysis.

Biomass burning emissions were generated from a preliminary version of the Global Fire Assimilation System (GFAS) developed in the MACC project (GFASv0, Kaiser et al., 2011). This version is very similar to the published inventory GFASv1.0 (Table 2; Kaiser et al., 2012), but with somewhat smaller totals (CO annual mass flux deviations for global and regional totals are less than $0.5 \%$ ). All biomass burning emissions are available with a daily resolution and have been injected into MOZART's lowest model level, where they are diffused rapidly within the mixing layer by the boundary layer diffusion scheme. $\mathrm{NO}_{\mathrm{x}}$ from lightning in MOZART is dependent on the distribution of convective clouds, following a parameterization of Price et al. (1997). Aircraft emissions of $\mathrm{NO}_{\mathrm{x}}$ and $\mathrm{CO}$ are also included in the model (Horowitz et al., 2003).

MOZART contains a detailed representation of both wet and dry deposition. Monthly means of dry deposition velocities for 35 species used in MOZART-3 were precalculated offline. For MACC the dry deposition fields originate from a monthly climatology derived from a 10 -year nudged simulation with the global chemistry climate model ECHAM5/MOZ (Richter and Schultz, 2011), where an interactive dry deposition scheme was implemented according to the resistance model of Ganzeveld and Lelieveld (1995) and Ganzeveld et al. (1998). For some of our sensitivity simulations the $\mathrm{CO}$ dry deposition velocity input fields have been exchanged by monthly mean velocity data for the year 2008 following the parameterization of Sanderson et al. (2003) and calculated with the TM5 chemical transport 

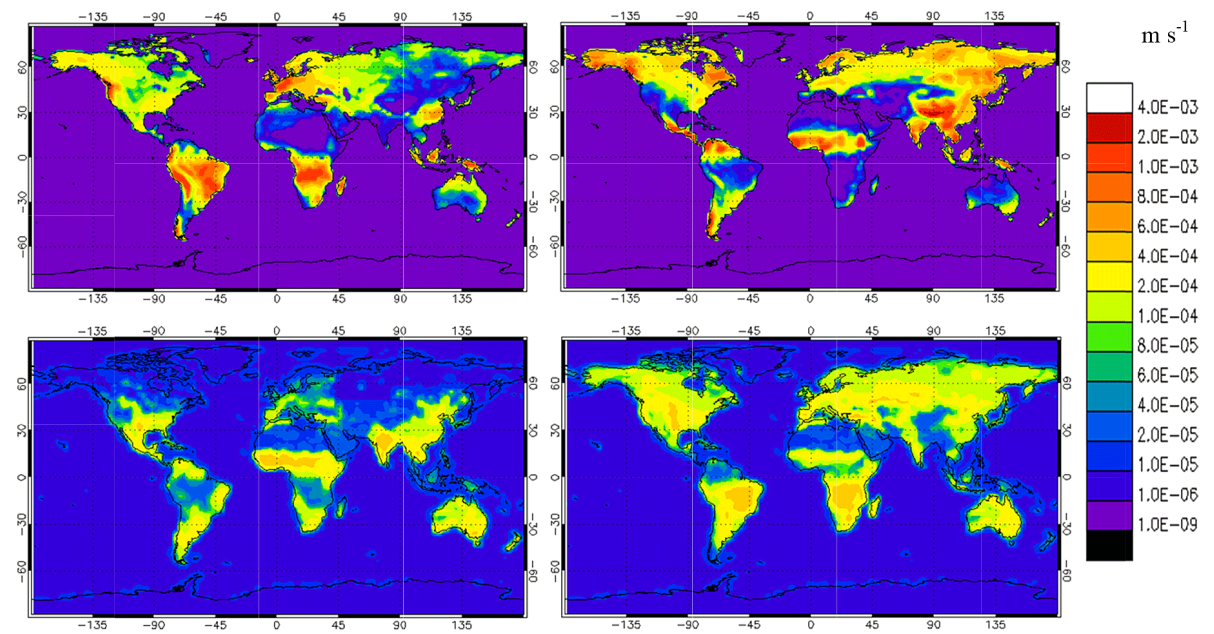

Figure 2. Monthly mean dry deposition velocities in metres per second for January (left) and July (right). Top panels: data derived with the ECHAM5/MOZ parameterization, bottom panels: data derived with the parameterization from Sanderson et al. (2003).

model (Huijnen et al., 2010). This parameterization assumes a strong dependence of the dry deposition on the soil moisture content (see Sect. 1), and the resulting global patterns look strikingly different from those of the original scheme. Figure 2 compares January and July dry deposition fields from both schemes. Deposition velocities according to the ECHAM5/MOZ scheme are dependent on air temperature, humidity, and vegetation types, while the Sanderson scheme is most sensitive to soil wetness and generates highest deposition fluxes over the tropics during the rainfall season and for some wet regions in the midlatitudes. Although dry deposition fluxes for $\mathrm{CO}$ are generally low compared to other species, it can be expected that the differences in magnitude and variability affect the $\mathrm{CO}$ concentrations, particularly for low-emission regions and during wintertime, when photochemical loss of $\mathrm{CO}$ is reduced.

Wet deposition in MOZART is represented as a first-order loss process, with additional in-cloud scavenging and belowcloud washout for soluble species (Horowitz et al., 2003). Mixing ratios at the surface are prescribed based on observations for several longer-lived species, including methane.

\section{Data sets used for evaluation}

\subsection{Surface station data}

Long-term measurements of key atmospheric species from surface observation sites around the globe are collected at the World Data Centre for Greenhouse Gases (WDCGG) operated by the World Meteorological Organization (WMO) Global Atmospheric Watch (GAW) programme (http://ds. data.jma.go.jp/gmd/wdegg/). We used monthly means of CO mixing ratios measured from 67 surface stations which provided data for all months in 2008; their positions on the globe are shown in Fig. 3 (red diamonds). The observation sites are operated by the NOAA Earth System Research Laboratory (USA), The Commonwealth Scientific and Industrial Research Organisation (CSIRO, Australia), Environment Canada, the Japan Meteorological Agency (JMA), the Czech Hydrometeorological Institute (CHMI), the German Federal Environmental Agency (UBA), the Swiss Federal Laboratories for Materials Science and Technology (EMPA), the Netherlands National Institute for Public Health and the Environment (RIVM), and the South African Weather Service (SAWS). We discarded mountain stations and stations which did not provide monthly means for all months in 2008 . Data were averaged over large-scale areas as depicted in Fig. 3 to minimize the influence from local pollution or meteorology for single stations. For evaluation we calculated area-averaged monthly means from all $\mathrm{NH}$ and $\mathrm{SH}$ stations as well as from those inside the regions defined in Fig. 3 (blue boxes).

\subsection{MOZAIC profiles}

The MOZAIC (Measurements of OZone and water vapour by Airbus In-service airCraft) programme collects ozone, $\mathrm{CO}$, odd nitrogen $\left(\mathrm{NO}_{\mathrm{y}}\right)$, and water vapour data, using automatic equipment installed onboard several longrange passenger airliners flying regularly all over the world (Marenco et al., 1998). MOZAIC products are available through the Ether French atmospheric database website: www.pole-ether.fr. Here we use $\mathrm{CO}$ data from vertical tropospheric transects taken in the vicinity of airports during ascent and descent. For more details of the data processing, see Elguindi et al. (2010). In 2008, only three aircraft were operating with the MOZAIC instrumentation, and therefore only a limited number of airports were visited regularly (13 airports with a total of 935 profiles). For the evaluation of the 


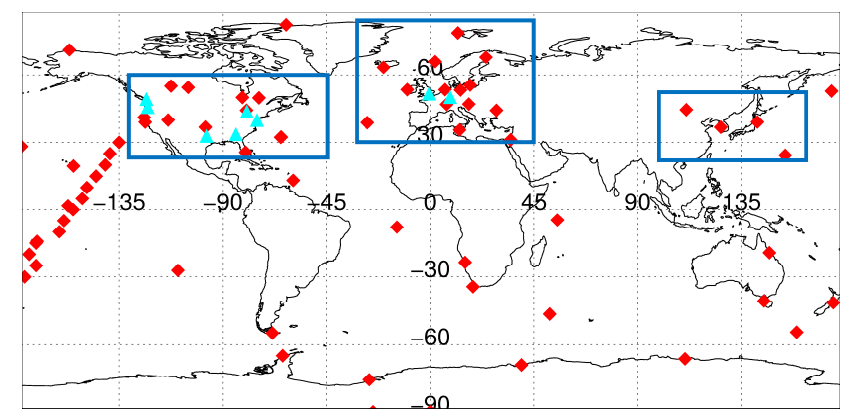

Figure 3. Locations of the surface stations (red diamonds) and MOZAIC airports (turquoise triangles) used for the model evaluation. Selected evaluation regions are marked with blue boxes.

2008 model simulations over Europe, we chose tropospheric data from the European airports of Frankfurt (Germany) and London (UK), where respectively 300 and 80 profiles were available. Furthermore we analysed an area average composed of the airports of Atlanta, Dallas, Philadelphia and Portland (OR) in the United States and Toronto and Vancouver in Canada, with 219 profiles altogether. This area average is meant to be representative of the North American area limited by the blue box in Fig. 3. There were no data over East Asia in 2008. We marked all airports used for evaluation with turquoise triangles in Fig. 3. The 3-hourly model results were interpolated to the times and locations of the MOZAIC observations; afterwards the profiles of each airport were combined to monthly means.

\subsection{MOPITT atmospheric columns}

The MOPITT (Measurement Of Pollution In The Troposphere) instrument onboard the EOS (Earth Observing System) Terra spacecraft provides tropospheric $\mathrm{CO}$ measurements on a global scale (Drummond and Mand, 1996; Deeter et al., 2004). At nadir view, MOPITT offers a horizontal resolution of $22 \mathrm{~km} \times 22 \mathrm{~km}$ and achieves global coverage in 2-3 days. MOPITT data used in this study correspond to the daytime $\mathrm{CO}$ total columns from the version 5 (V5) level 2 (L2) product (http://www2.acd.ucar.edu/ mopitt/products), which is based on both near-infrared (NIR) and thermal-infrared (TIR) radiances (Deeter et al., 2013). Exploiting TIR and NIR radiances together increases the sensitivity for $\mathrm{CO}$ in the lowermost troposphere (Worden et al., 2010; Deeter et al., 2011). The observations used here are area-averaged monthly means from the regions defined in Fig. 3 (blue boxes). The modelled CO total columns were calculated by applying the MOPITT averaging kernels. Details about the method of calculation are given in Deeter et al. (2004) and Rodgers (2000).

\subsection{IASI atmospheric columns}

IASI (Infrared Atmospheric Sounding Interferometer) is a nadir-looking Fourier transform spectrometer (FTS), launched in 2006 on the polar orbiting MetOp-A satellite. Its spectral resolution of $0.5 \mathrm{~cm}^{-1}$ (apodized), along with continuous spectral coverage from 645 to $2760 \mathrm{~cm}^{-1}$ allows the column and profile retrievals of several trace gases, twice daily at any location (Clerbaux et al., 2009). For carbon monoxide, profiles are retrieved using an optimal estimation approach, implemented in the Fast Optimal Retrievals on Layers for IASI (FORLI) software (Hurtmans et al., 2012). The spectra are processed in near-real time, and the CO profiles are distributed with error covariance, averaging kernels and quality flags information (www.pole-ether.fr). The IASI $\mathrm{CO}$ product was validated against ground-based observations (Kerzenmacher et al., 2012), aircraft data (De Wachter et al., 2012), and satellite measurements (George et al., 2009). The FORLI-CO column (v20100815) values used here are daytime data. For this study area-averaged monthly means from the regions defined in Fig. 3 (blue boxes) are used.

\section{MOZART sensitivity simulations}

For the purpose of analysing the model sensitivity to $\mathrm{CO}$ emission and dry deposition fluxes, we conducted seven MOZART simulations for the year 2008 as summarized in Table 3. Our basic simulation MI is based on the surface boundary condition data presented in Sect. 2. Following the findings from the MACC reanalysis and from previous global studies, the negative model bias in boreal winter and spring $\mathrm{CO}$ concentrations could be explained either by missing sources from surface emissions or by an overestimation of the surface dry deposition sink. Thus we expanded our basic model simulation for the year 2008 with a suite of six sensitivity simulations covering the potential sources of uncertainty in the surface fluxes. These sensitivity simulations differ in their specific perturbation of the emission inventories and dry deposition velocities.

$\mathrm{NH} \mathrm{CO}$ concentrations in winter and spring are mostly controlled by anthropogenic emissions from traffic and energy consumption. MI+AN tests for the hypothesis that anthropogenic $\mathrm{CO}$ emissions are underestimated significantly. To incorporate also the anthropogenic VOC precursors, we added the simulation MI+VOC with doubled anthropogenic VOC emissions. With respect to natural sources we performed the simulation $\mathrm{MI}+\mathrm{BIO}$, where both biogenic $\mathrm{CO}$ and VOC emissions have been doubled. To conclude the sensitivities on the $\mathrm{CO}$ emission sources, the simulation $\mathrm{MI}+\mathrm{BB}$ used doubled $\mathrm{CO}$ biomass burning emissions from GFAS. Although these scenarios look quite extreme, they are useful to illustrate the various effects of the emission sectors on the global and regional $\mathrm{CO}$ concentrations and their annual variations. Furthermore, uncertainty levels of emissions, 
particularly for less developed countries and for natural emissions, are still high (e.g. Lamarque et al., 2010).

The simulation MI-DEP tests for the alternative dry deposition velocity scheme from Sanderson et al. (2003). Finally, our simulation MI-OPT applied a modified CO traffic emission scaling for North America and Europe only, which exhibits a seasonal variation as shown in Table 4. This simulation utilized the same dry deposition parameterization as in MI-DEP. The details of the optimization are described in Sect. 5.4 below.

All model simulations were analysed for the year 2008 but started at 1 July 2007 to allow for a spin-up period. Tracer initial conditions were taken from the MACC reanalysis which included assimilation of $\mathrm{CO}, \mathrm{O}_{3}$, and $\mathrm{NO}_{2}$ satellite information. It should be noted that 2008 was within the 3 years with lowest atmospheric $\mathrm{CO}$ concentrations out of the 13 years (2000-2012) where satellite observations were available (Worden et al., 2013). Modelled tropospheric CO mixing ratios and total column densities are evaluated with the observational data introduced in Sect. 3. Impacts from uncertainties in the modelling of $\mathrm{OH}$ on the $\mathrm{CO}$ budget will be discussed in Sect. 6.

\section{Results}

\subsection{MACCity emissions}

First we compare our base case simulation (MI), using MACCity anthropogenic and natural emissions, to GAW observations gathered from the WDCGG database. Figure 4 shows monthly means of surface station $\mathrm{CO}$ mixing ratios and of near-surface model mixing ratios. Modelled monthly means from 3-hourly values were interpolated to the station location for 67 stations ordered by latitude.

The station data exhibits the highest values and also the largest variability at northern midlatitudes $\left(30-60^{\circ} \mathrm{N}\right)$ during wintertime, with mean January mixing ratios of more than $300 \mathrm{ppb}$ for three stations, namely Hegyhatsal (Hungary), Payerne (Switzerland), and Black Sea (Romania). In addition, Payerne exceeded this threshold in February 2008, and the station Tae-ahn (South Korea) reached monthly mean mixing ratios of more than $300 \mathrm{ppb}$ for March to May 2008 (not shown). NH mixing ratios are generally higher in winter (and spring) than in summer. The station observations in the Southern Hemisphere show a relatively uniform distribution both in winter and summer, with background mixing ratios of about 40-70 ppb. Modelled NH CO mixing ratios are mostly lower than the observations, particularly during wintertime. In January, the model underestimates the mixing ratios for the Arctic stations by about $50 \mathrm{ppb}$. In the SH, model and observations match better, with an overestimation of up to $10 \mathrm{ppb}$ being typically seen. The global distributions of atmospheric CO can be derived with high spatial resolution from the satellite total column

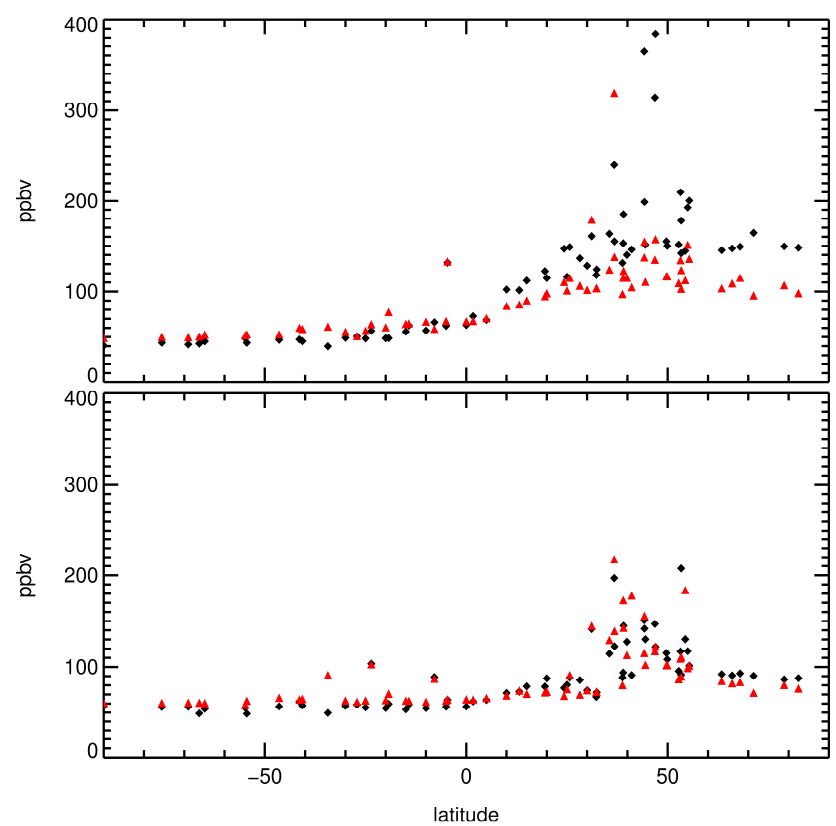

Figure 4. Monthly mean CO mixing ratios from the 67 surface stations available in WDCGG used for this study sorted for geographical latitude (black rhombi) and modelled near-surface mixing ratios from simulation MI for the same locations (red triangles). Upper panel: January 2008; lower panel: July 2008.

observations. As shown in Fig. 5, the MOPITT and IASI products agree well for most regions. MOPITT total columns are somewhat higher than IASI for several NH regions in January, but IASI attains a better spatial coverage. The MI simulation is able to reproduce the general features and levels of the satellite $\mathrm{CO}$ distribution, but calculates higher $\mathrm{CO}$ columns over India, and slightly lower columns for other polluted regions like Europe, North America, and East Asia (see relative difference panels in Fig. 5). The northern African biomass burning regions in January are less pronounced in the model than in the satellite data, while there seems to be an overestimation from the model over SH tropical western Africa in July.

\subsection{Sensitivity to emissions}

The comparison of monthly means from near-surface model mixing ratios with monthly mean surface station data from the WDCGG is shown in Fig. 6. The data are averaged over the Northern and Southern Hemisphere as well as for the regions Europe, North America, and East Asia. The model bias is given for the base simulation MI and for the sensitivity simulations $\mathrm{MI}+\mathrm{AN}, \mathrm{MI}+\mathrm{BIO}$, and $\mathrm{MI}+\mathrm{BB}$.

The simulation with MACCity emissions (MI) underestimates the observed surface mixing ratios in the $\mathrm{NH}$ in all seasons except summer, with low biases exceeding $20 \mathrm{ppb}$ from December to April and exceeding $40 \mathrm{ppb}$ in January. The largest underestimation of about $75 \mathrm{ppb}$ is found over 

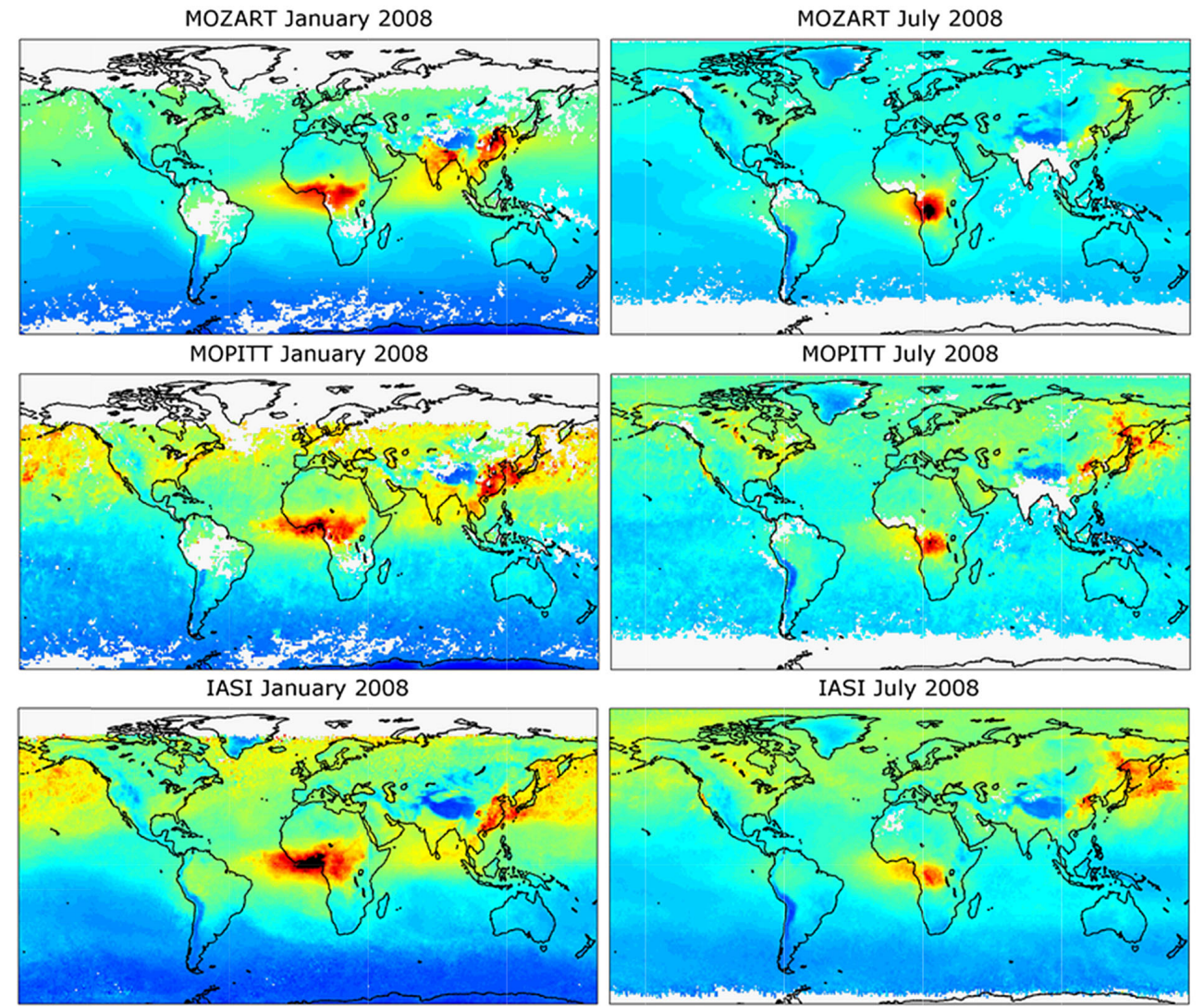

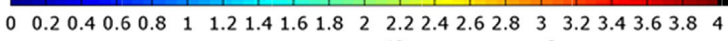

$\mathrm{CO}$ total column $\left(\times 10^{18}\right.$ molecules $\left./ \mathrm{cm}^{2}\right)$

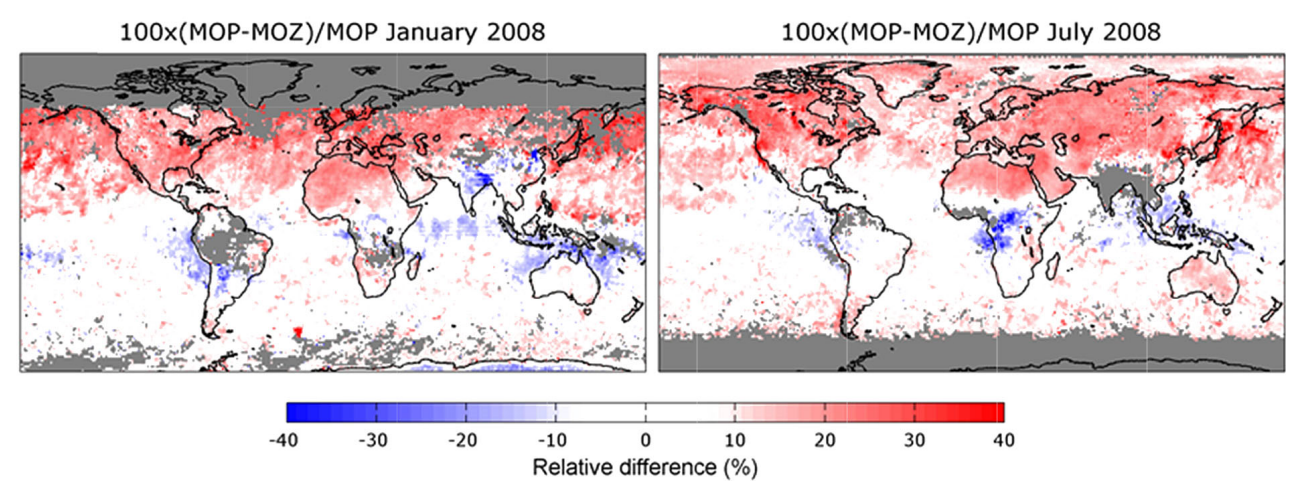

Figure 5. Monthly mean CO total column densities for January and July 2008 as observed from IASI and MOPITT, and calculated from simulation MI smoothed by MOPITT averaging kernels. The relative difference between the model simulations and MOPITT observations $(100 \times($ MOPITT - MOZART) / MOPITT $)$ is seen in the bottom panels. 
Table 3. Description of MOZART 2008 sensitivity simulations.

\begin{tabular}{|c|c|c|c|c|c|}
\hline Simulation & Anthropogenic emissions & Biogenic emissions & $\begin{array}{l}\text { Biomass burning } \\
\text { emissions }\end{array}$ & Dry deposition & $\begin{array}{l}\text { Global total CO } \\
\text { source added to } \\
\text { MI in } \mathrm{Tg} \mathrm{yr}^{-1}\end{array}$ \\
\hline MI & MACCity & MEGANv2.0 & GFASv1 & ECHAM5/MOZ & - \\
\hline $\mathrm{MI}+\mathrm{AN}$ & $\begin{array}{l}\text { MACCity, anthropogenic CO } \\
\text { emissions doubled }\end{array}$ & MEGANv2.0 & GFASv1 & ECHAM5/MOZ & 586 \\
\hline $\mathrm{MI}+\mathrm{VOC}$ & $\begin{array}{l}\text { MACCity, anthropogenic VOC } \\
\text { emissions doubled }\end{array}$ & MEGANv2.0 & GFASv1 & ECHAM5/MOZ & 84 \\
\hline $\mathrm{MI}+\mathrm{BIO}$ & MACCity & $\begin{array}{l}\text { MEGANv2.0, biogenic CO } \\
\text { and VOC emissions doubled }\end{array}$ & GFASv1 & ECHAM5/MOZ & 535 \\
\hline $\mathrm{MI}+\mathrm{BB}$ & MACCity & MEGANv2.0 & $\begin{array}{l}\text { GFASv1, CO biomass } \\
\text { burning emissions doubled }\end{array}$ & ECHAM5/MOZ & 323 \\
\hline MI-DEP & MACCity & MEGANv2.0 & GFASv1 & $\begin{array}{l}\text { Sanderson et al. } \\
\text { (2003) }\end{array}$ & 68 \\
\hline MI-OPT & $\begin{array}{l}\text { MACCity, refined traffic CO scaling } \\
\text { for North America and Europe only }\end{array}$ & MEGANv2.0 & GFASv1 & $\begin{array}{l}\text { Sanderson et al. } \\
(2003)\end{array}$ & 87 \\
\hline
\end{tabular}

Table 4. Monthly scaling factors for CO traffic emissions over North America and Europe as applied in simulation MI-OPT.

\begin{tabular}{lrrrrrrrrrrrr}
\hline & Jan & Feb & Mar & Apr & May & Jun & Jul & Aug & Sep & Oct & Nov & Dec \\
\hline North America & 1.25 & 1.5 & 2 & 1.33 & 1 & 1 & 1 & 1 & 1 & 1 & 1 & 1 \\
Europe & 4.5 & 3.33 & 3.33 & 3 & 1.5 & 1 & 1 & 1.25 & 1.5 & 2 & 2.5 & 2.5 \\
\hline
\end{tabular}

Europe. During summer, the modelled CO mixing ratios match the observations on average, with a slight underestimation for Europe and overestimation for North America. As biogenic and biomass burning emissions peak in the $\mathrm{NH}$ summertime, their influence on $\mathrm{NH}$ mixing ratios is greatest during this season. Generally, the lifetime of $\mathrm{CO}$ is much shorter during summer, because of the greater abundance of the $\mathrm{OH}$ radical (Novelli et al., 1998). This will reduce the influence of direct $\mathrm{CO}$ emissions relative to the oxidation source from methane and other VOCs.

East Asian observed mixing ratios agree relatively well with the MI simulation for the whole year, at least for the four surface stations which could be taken into account here. This reasonable model performance is probably due to the recently updated regional emission information and to the better emission predictions for China in the MACCity inventory (Riahi et al., 2011). For the sake of completeness we also report here the good agreement between simulated and observed SH mixing ratios; only a small positive model bias of 5 to $10 \mathrm{ppb}$ is found all year round in all our simulations.

Similarly to the surface mixing ratios, the modelled CO total columns are compared with the observed total columns from MOPITTv5 and IASI (Fig. 7). The satellite observations are more representative of the free troposphere and accomplish a substantial coverage over the regions of interest. Due to the differences in spatial sampling between the two instruments, and the different methods (based on different a priori assumptions) used to obtain the $\mathrm{CO}$ total column product, a spread between the two satellite products of up to $9 \%$ averaged over the $\mathrm{NH}$ exists (see also Worden et al., 2013). Over the NH, IASI observed lower total columns than
MOPITT from October to March and higher total columns in July/August. The findings from the surface station evaluation of the MI simulation generally hold true also for the total columns, with a few differences: MI always underestimated NH MOPITT total columns as well as the IASI columns from January to October. Largest biases occur for MOPITT-MI in March: $18 \%(\mathrm{NH}), 24 \%$ (Europe), and $22 \%$ (North America).

As expected, in the sensitivity simulation with doubled anthropogenic emissions (MI+AN, see Figs. 6 and 7), the modelled CO total columns overestimated the observed values in all regions. However, deviations from the observations are smaller than in the MI simulation in January and February over the $\mathrm{NH}$, which can mostly be attributed to the North American and European regions. The overestimation is less pronounced during the summer months, when the CO loss due to reaction with $\mathrm{OH}$ gains more importance.

The simulation MI+BIO (doubled biogenic CO and VOC emissions) enhanced the modelled surface $\mathrm{CO}$ mixing ratios by 20 to $40 \mathrm{ppb}$ for all regions. Since the biogenic emissions mainly occur in the tropics and on the $\mathrm{NH}$ landmasses with a summer maximum, doubling of biogenic emissions leads to an overestimation over the whole $\mathrm{NH}$, with a maximum in summer. SH concentrations are biased high during all months for both surface mixing ratios and total columns. The MI+BB simulation (doubled CO biomass burning emissions) leads to overestimation of the peak surface mixing ratios during $\mathrm{NH}$ spring and summer, as can be noticed in the wildfire-influenced regions of North America, and East Asia (Fig. 6). As compared with satellite total columns, the $\mathrm{MI}+\mathrm{BB}$ simulation is able to follow the annual course of 

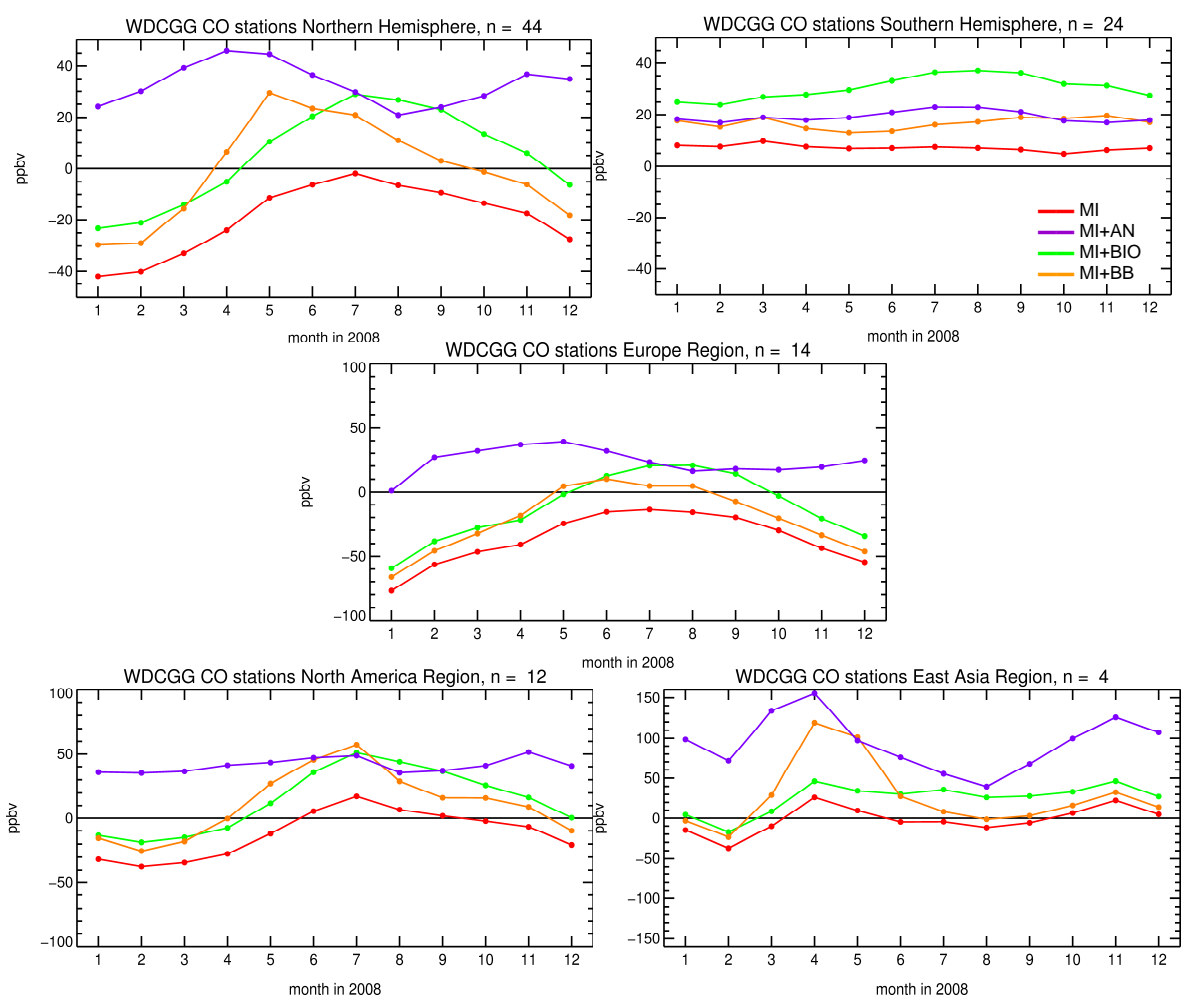

Figure 6. Bias of modelled 2008 monthly mean surface level mixing ratios from the MOZART simulations MI, MI+AN, MI+BIO, and $\mathrm{MI}+\mathrm{BB}$ compared to observations from WDCGG. $n$ denotes the number of stations used.

IASI observations better than the other runs and also better than the MOPITT seasonality (Fig. 7). As pointed out by Worden et al. (2013), IASI is more sensitive to transient biomass burning events than MOPITT. Such events are also included in our simulations through application of daily GFAS emissions (Kaiser et al., 2012), with enhanced emission intensity for MI+BB. Neither of the simulations with enhanced biogenic $(\mathrm{MI}+\mathrm{BIO})$ or wildfire emissions $(\mathrm{MI}+\mathrm{BB})$ are able to improve the negative bias seen by the models in $\mathrm{NH}$ winter without introducing significant overestimations during boreal summer and over the SH. Thus a bias in the biogenic or biomass burning emission inventories is not likely to explain the modelled underestimation of $\mathrm{CO}$ during $\mathrm{NH}$ winter.

To account for the uncertainties in the emissions of anthropogenic $\mathrm{CO}$ precursors, we also ran MOZART using MACCity emissions together with doubled VOC anthropogenic emissions (MI+VOC). These increased emissions are able to enhance wintertime and spring surface $\mathrm{CO}$ mixing ratios by 5 to $15 \mathrm{ppb}$ (Fig. 8, grey lines). Although the improvement with added VOC emissions is small, it does not lead to a $\mathrm{CO}$ overestimate in summer and could therefore add a small portion to the missing NH CO concentrations, primarily in spring.

\subsection{Sensitivity to dry deposition}

Surface layer mixing ratios from the sensitivity simulation MI-DEP, which used the parameterization by Sanderson et al. (2003) for deposition velocities, together with the MACCity emissions are displayed in Fig. 8. As compared with MI, the reduced deposition fluxes over the NH landmasses result in higher mixing ratios of around $10 \mathrm{ppb}$ in summer and $20 \mathrm{ppb}$ in winter, when $\mathrm{OH}$ concentrations are low and the planetary boundary layer is usually shallower. Over Europe, where the differences between the two schemes are quite large, wintertime mixing ratios are higher by $30 \mathrm{ppb}$, whereas from May to September values match the observations very well. Mixing ratios over East Asia are moderately increased (less than $20 \mathrm{ppb}$ all year round), while over North America the summer and autumn values of MI-DEP are biased high compared with the observations. Over the $\mathrm{SH}$, this simulation decreases the tropospheric mixing ratios of CO by up to $5 \mathrm{ppb}$ (August-October), which may be due to the increased deposition fluxes over Africa and South America (see Fig. 8). Overall the use of the parameterization by Sanderson et al. (2003) improved the model results significantly but is not able fill the gap to boreal wintertime CO observations, particularly over Europe, without additional modifications to the (anthropogenic) emissions. 

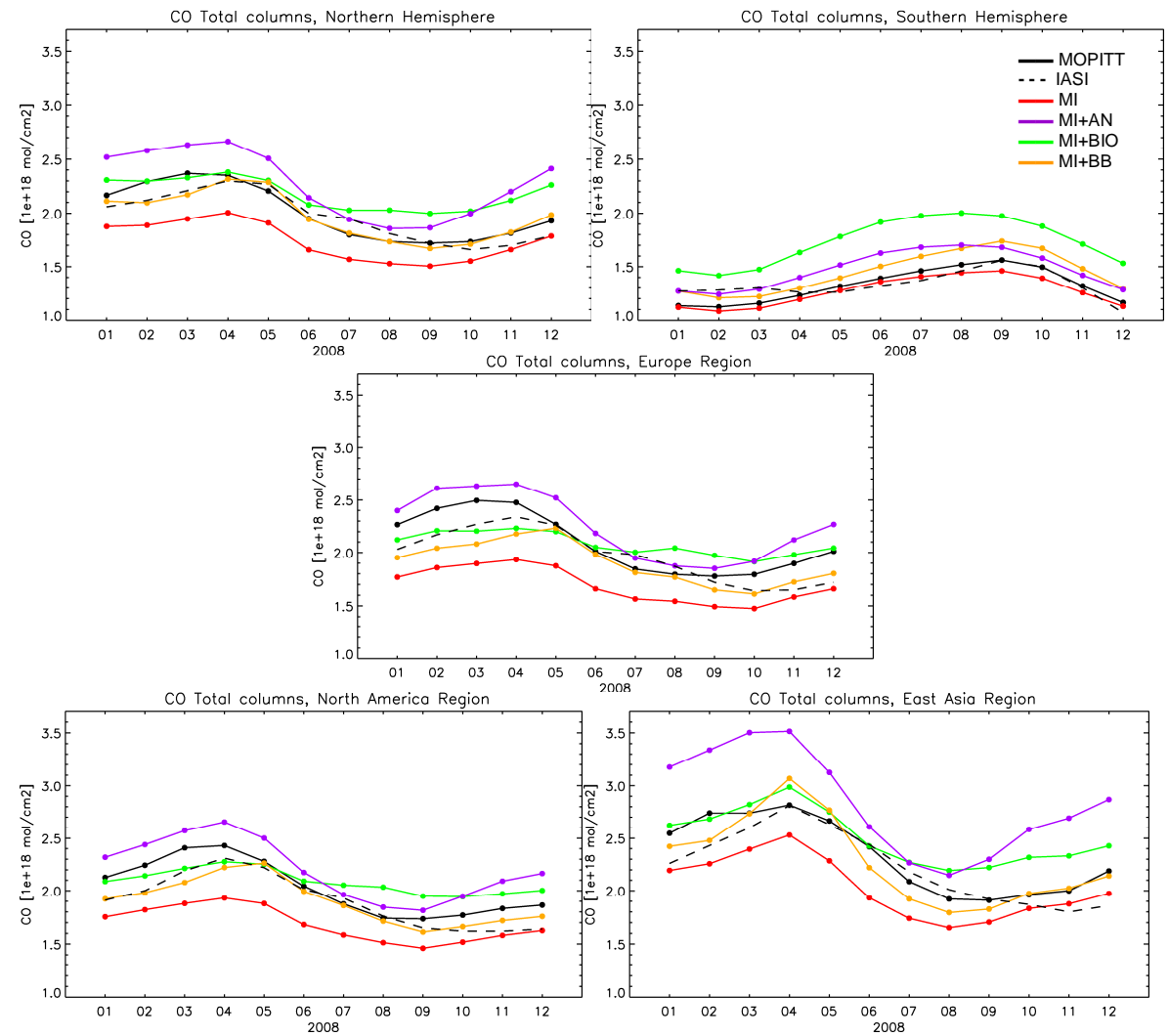

Figure 7. CO total columns from MOPITT and IASI satellite observations compared to 2008 monthly modelled columns from the MOZART simulations $\mathrm{MI}, \mathrm{MI}+\mathrm{AN}, \mathrm{MI}+\mathrm{BIO}$, and $\mathrm{MI}+\mathrm{BB}$.

\subsection{Optimized approach}

As indicated in Sect. 2, the MACCity inventory is based on the ACCMIP emissions for the year 2000. Lamarque et al. (2010) pointed out that for USA, Europe, and East Asia published regional inventories have been given preference, notably EPA (Environmental Protection Agency) data for USA, EMEP (European Monitoring and Evaluation Programme) data for Europe, and REAS (Regional Emission inventory in ASia) data for East Asia. The EPA reported on air pollution trends of US cities between 1990 and 2008 and found maximal decadal decreases in $\mathrm{CO}$ pollution of 60 to $80 \%$ for 1990 to 2008 (Riahi et al., 2011). Consequently, in the RCP8.5 scenario an exposure-driven spatial algorithm for the downscaling of the regional emission projection has been employed. This led to the highest emission reduction of up to $80 \%$ per decade in those grid cells with the highest exposure for regions where emissions are reduced due to the implementation of air pollution control measures, e.g. USA and Europe. For regions with increasing emissions (e.g. in Asia), emissions increase proportionally to the acceleration of the economic activity (Riahi et al., 2011). In Fig. 9, the regionally aggregated development of $\mathrm{CO}$ anthropogenic emissions from 2000 to 2050 under the RCP8.5 scenario is shown. Although RCP8.5, which is used in MACCity, is a scenario with relatively high greenhouse gas emissions, the $\mathrm{CO}$ anthropogenic emissions decrease slowly in the first decade (2000-2010), mostly driven by strong emission reductions in the OECD countries. Road traffic contributes a major part of the anthropogenic $\mathrm{CO}$ emissions in the industrialized countries. Pouliot et al. (2012) compared regional emission inventories for Europe and North America for 2005 and reported $85 \%$ of North American anthropogenic CO emissions and $43 \%$ of European emissions to originate from mobile sources. The discrepancy could be explained partly by different methods to derive the inventories for the domains and partly by the higher fraction of gasoline vehicles in North America. Traffic emissions in the OECD countries decrease in MACCity by $46 \%$ (from 119 to $44 \mathrm{Tg} \mathrm{yr}^{-1}$ ) for the period 2000 to 2010. For Asia, total emissions are estimated to increase by $10 \%$ until 2020, with the largest growth rate from industrial emissions and with other emission sectors stagnating.

Our simulation MI-OPT tests for the hypothesis that CO emissions from cars (or other sources that largely follow the same spatial allocation as traffic emissions) are not considered adequately in the MACCity estimate: estimates of automobile emissions are based on defined driving cycles, which do not include short trips, when much more $\mathrm{CO}$ is emitted 

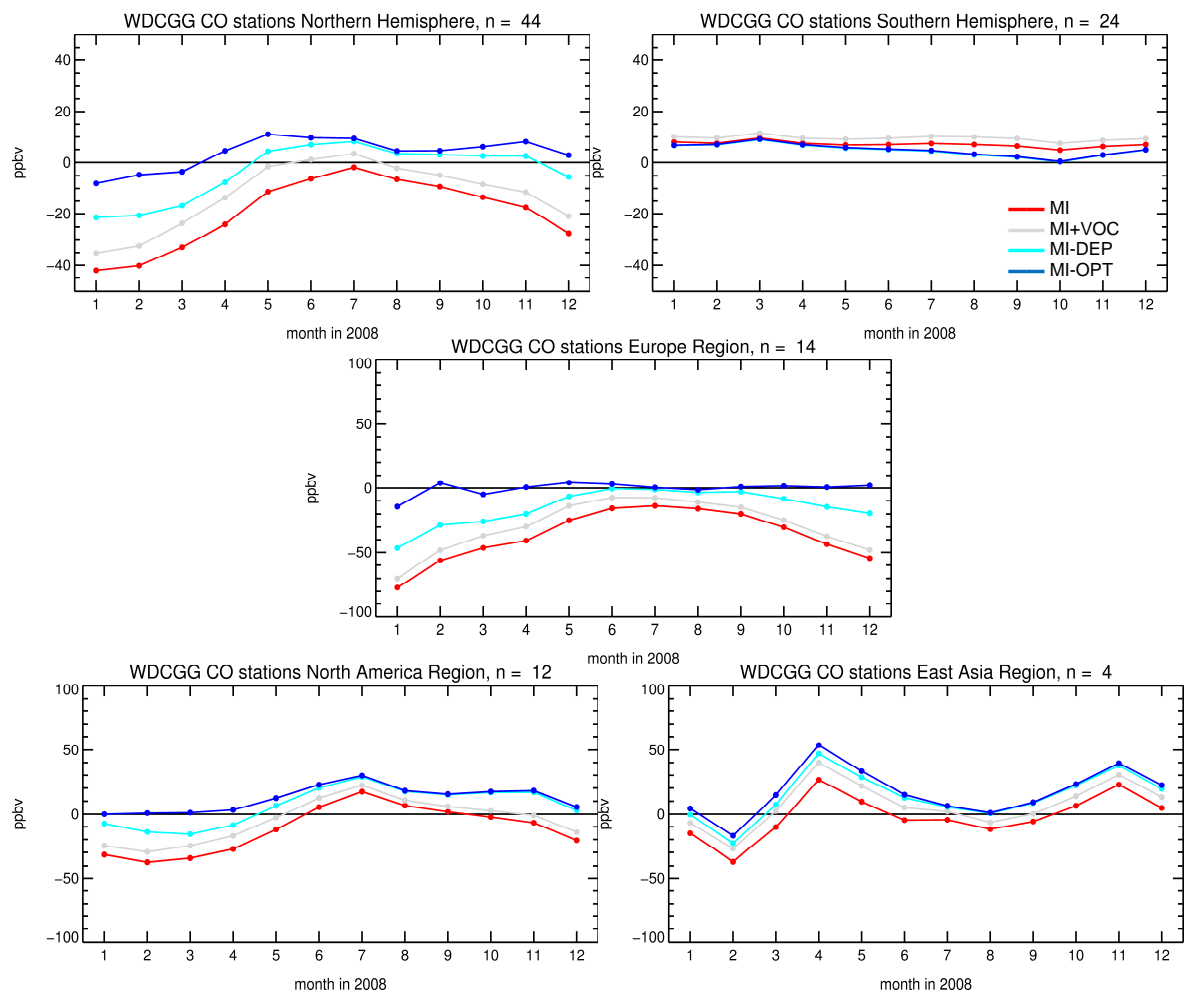

Figure 8. As in Fig. 6 but for the simulations MI (red), MI+VOC (grey), MI-DEP (light blue), and MI-OPT (dark blue).
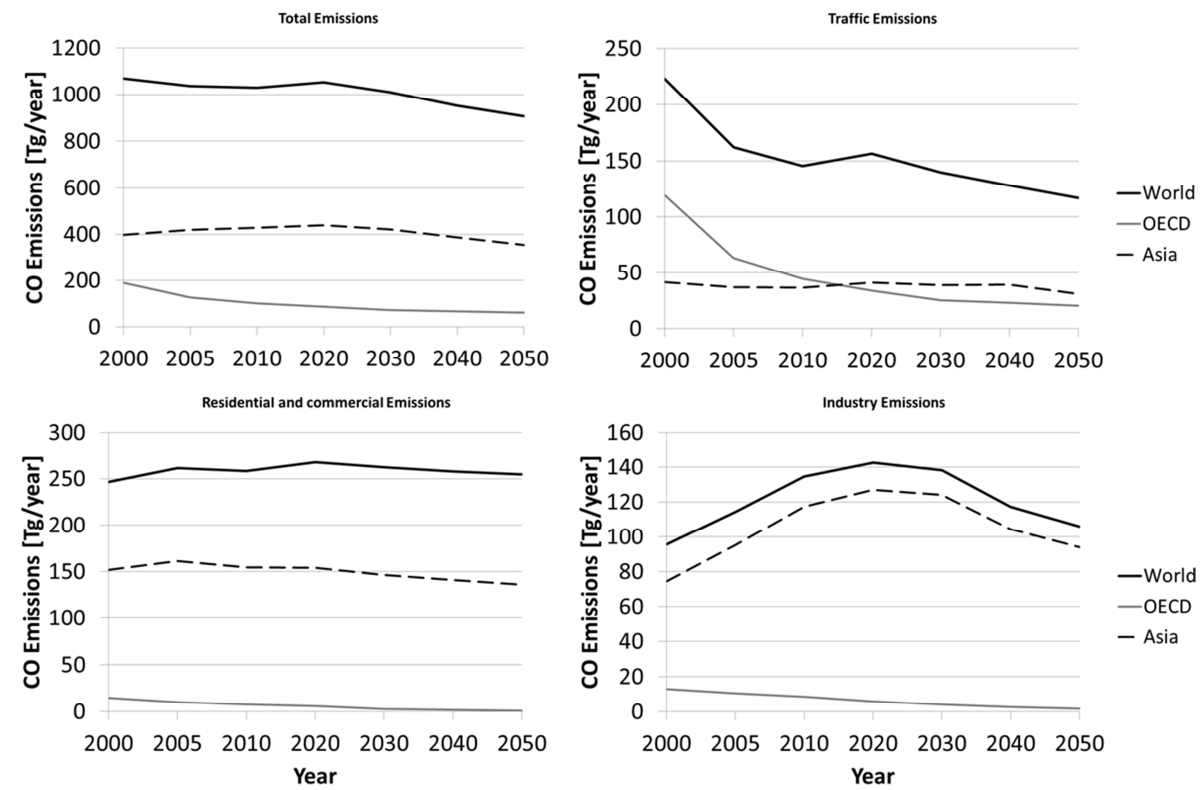

Figure 9. Annual CO anthropogenic emissions 2000-2050 from different sectors in the RCP8.5 scenario, worldwide, for OECD countries and for Asia.

under cold-engine conditions (Parrish, 2006; Kopacz et al., 2010; Klemp et al., 2012). This could induce a significant underestimation of traffic $\mathrm{CO}$ emissions in the emission inventory, in particular during winter. This effect is potentially amplified by an unrealistic reduction in emissions from 2000 to 2010 in MACCity. We note that our simulations do not allow the attribution of the missing $\mathrm{CO}$ source to the traffic sector, although (as indicated above) there are reasons to 

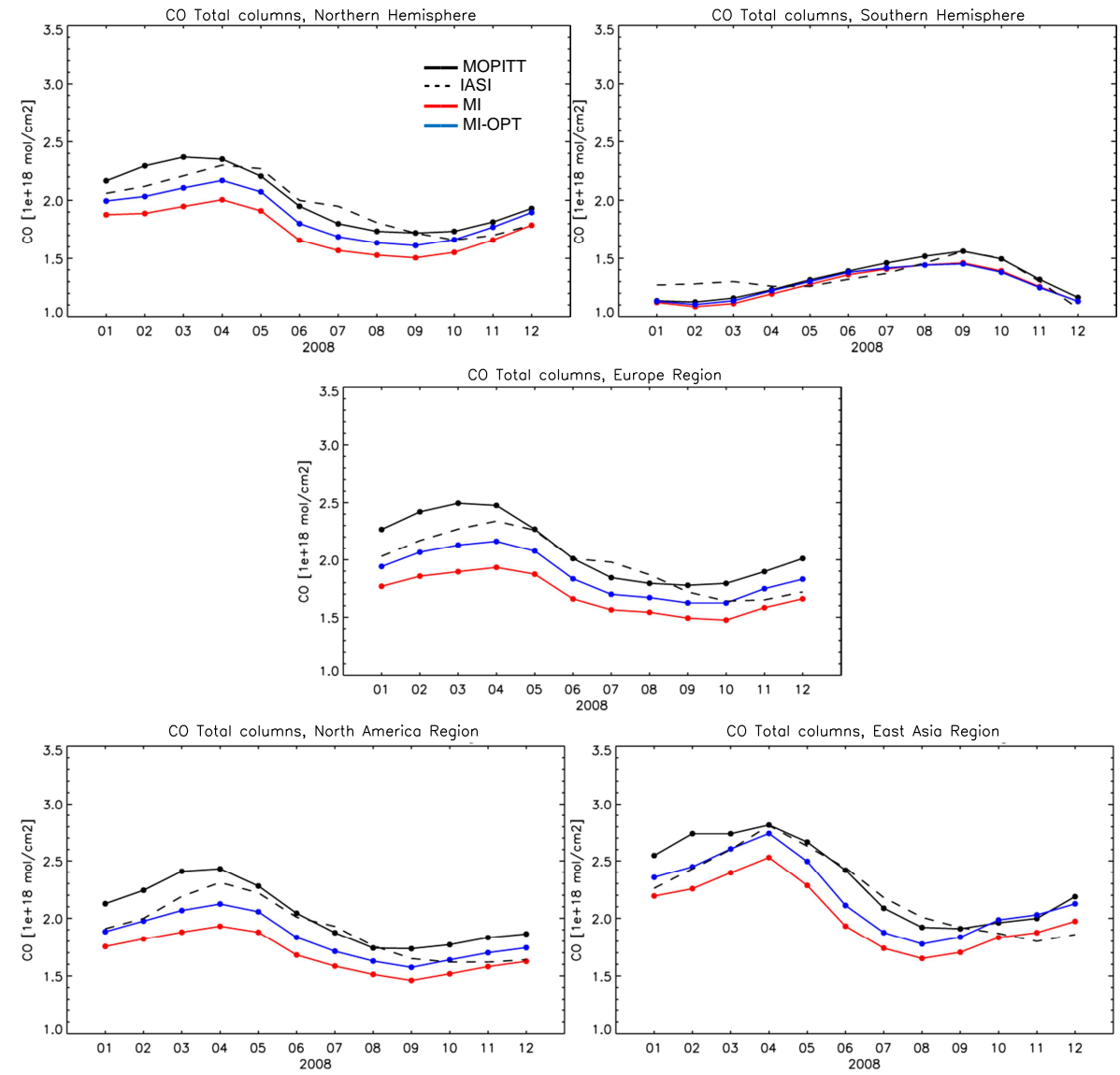

Figure 10. As in Fig. 7 but for the simulations MI (red) and MI-OPT (dark blue).

believe that this sector contributes to the problem. In reality it may well be a combination of underestimates from various sectors, many of which are poorly constrained. One such sector, which is particularly relevant during winter, is household wood burning (H. Denier van der Gon, personal communication, 2012). Clearly, a more systematic assessment of emission uncertainties would be helpful.

Our first sensitivity simulations using globally or regionally increased traffic emissions resulted in $\mathrm{CO}$ mixing ratios that were too high in summer, and in certain regions, particularly over Asia (not shown). Based on these initial results and after two more iterations, we defined refined scaling factors for the $\mathrm{CO}$ road traffic emissions in the simulation MIOPT to account for missing emissions like under cold-start conditions with monthly scaling factors for Europe and North America only, as described in Table 4. The total added emissions from this simulation are only $19 \mathrm{Tg} \mathrm{yr}^{-1}$ globally, compared to $586 \mathrm{Tg} \mathrm{yr}^{-1}$ of additional emissions in the simulation MI+AN (Table 3). Applying the modified scaling factors enhances wintertime $\mathrm{CO}$ emissions only for the European and the North American domain and also accounts for realistic $\mathrm{CO}$ concentrations from long-range transport. Simultaneously, MI-OPT takes into account the improved dry deposition parameterization by Sanderson et al. (2003) as in MI-DEP.

The simulation MI-OPT is compared with surface observation as shown in Fig. 8. The simulation is able to shift effectively wintertime $\mathrm{CO}$ mixing ratios to higher values for Europe and North America without significantly increasing the $\mathrm{CO}$ mixing ratios in East Asia. Applying the scaling factors given in Table 4 results in an almost perfect match to the GAW station observations for Europe and on the NH average. The same holds true over North America for the months December to May. Where mixing ratios with the MI emissions were already biased high, as for North America in summer or for East Asia in spring and autumn, these overestimations can likely be attributed mostly to natural emissions. This can be deduced from the MI+BB and MI+BIO simulations, where mixing ratios for these regions are enhanced similarly (Fig. 6).

The comparison of total $\mathrm{CO}$ columns from MI-OPT to MOPITT and IASI satellite observations is shown in Fig. 10. $\mathrm{NH}$ mean columns are enhanced by $6-9 \%$ with respect to the MI simulation, but not enough to match the values from the satellite observations, which are still higher except during October to December 2008. Similar changes can be seen for 

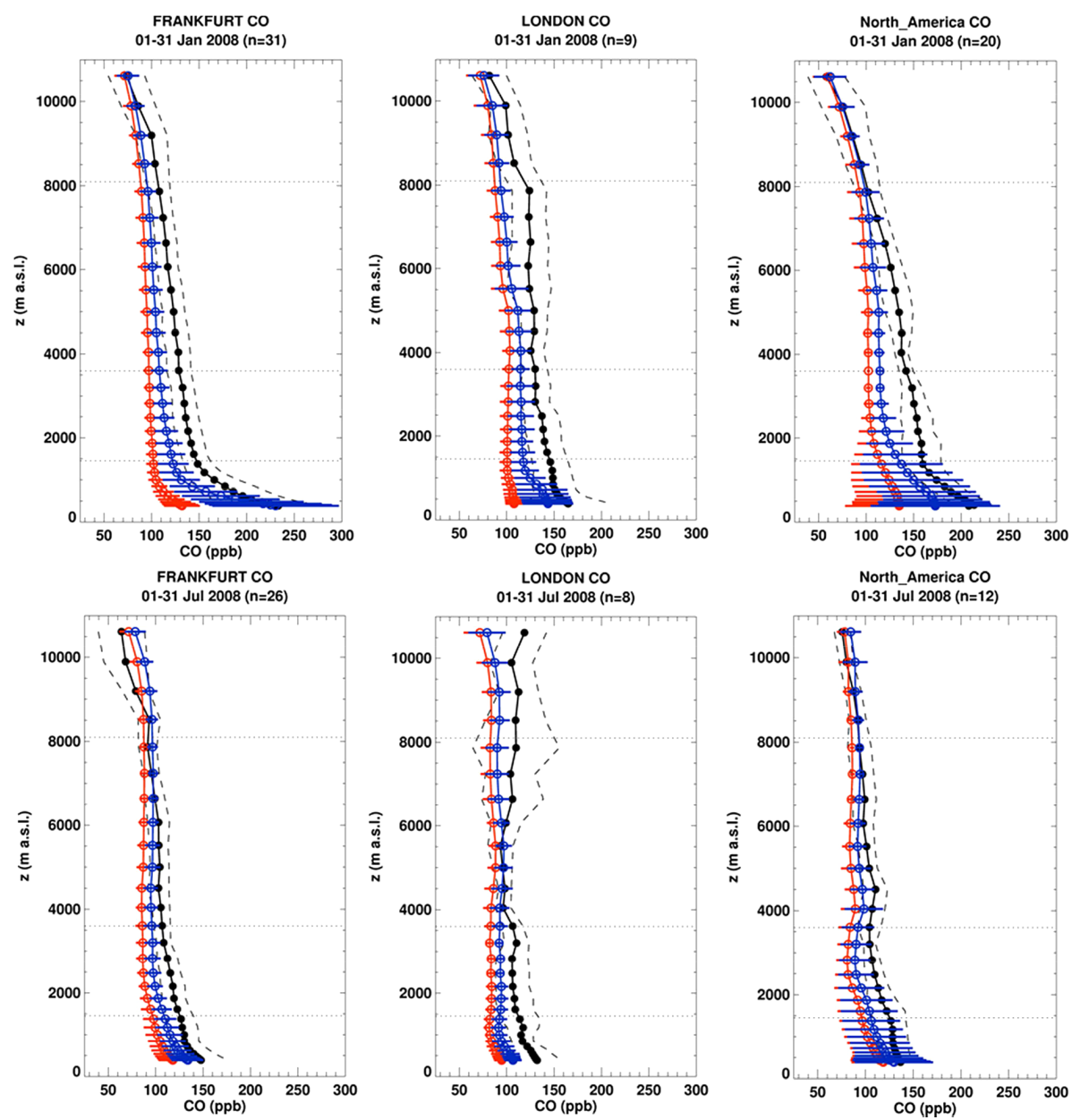

Figure 11. Monthly averaged CO profiles from MOZAIC ascents and descents at selected airports evaluated at model levels (black solid lines). North_ America is composed of six airports in the United States and Canada; $n$ is the total number of flights. The coloured lines depict model results interpolated to the same time and position from the simulations MI (red) and MI-OPT (blue). Black dotted lines indicate the range of the MOZAIC observations within the month; horizontal lines give the corresponding range of the model results.

the regional averages, with the largest increase over Europe $(8-12 \%)$ and somewhat lower differences for North America $(7-10 \%)$ and East Asia (7-9\%). In summer and autumn, most of the enhancement is due to the changes in the dry deposition parameterization, while in winter and spring the increased emissions dominate the optimization (not shown). $\mathrm{CO}$ total columns over the $\mathrm{SH}$ remain mostly unchanged with respect to the simulation MI.

The evaluation results from surface stations and satellite observations are complemented by the comparison with MOZAIC profiles over the airports of Frankfurt (Germany) and London (UK) and a composite of six airports over North America (Fig. 11). In January 2008 the simulation MI is biased low with maximal differences in the lowest model level (ca. $100 \mathrm{ppb}$ over Frankfurt, $55 \mathrm{ppb}$ over London, and $80 \mathrm{ppb}$ for North American airports). The model underestimates CO up to the tropopause, with smaller biases as the upper troposphere is approached. In July, MI shows a negative bias of
$20-40 \mathrm{ppb}$ throughout the lower troposphere. CO mixing ratios from the simulation MI-OPT are generally higher than those from MI, thus reducing the bias with respect to the observations. In January, the negative bias is reduced to 5$30 \mathrm{ppb}$ near the surface, but may still reach up to $40 \mathrm{ppb}$ in some parts of the free troposphere, whereas in July, MI-OPT mixing ratios are consistently $10-15$ ppb higher than those from MI. We speculate that the continued underestimation of free-tropospheric $\mathrm{CO}$ results from a low bias in vertical transport mass fluxes or from the MOZART parameterization of surface emissions, which are all injected into the lowest model layer, whereas some fraction of the emissions (smoke stacks, fires) might in reality be released at higher altitudes.

How the modification of wintertime NH CO emissions affects other trace gases is shown for simulation MI-OPT in Fig. 12. First we show the differences in the $\mathrm{CO}$ distributions compared with the simulation MI-DEP (top left panel): European and North American surface mixing ratios are enhanced 

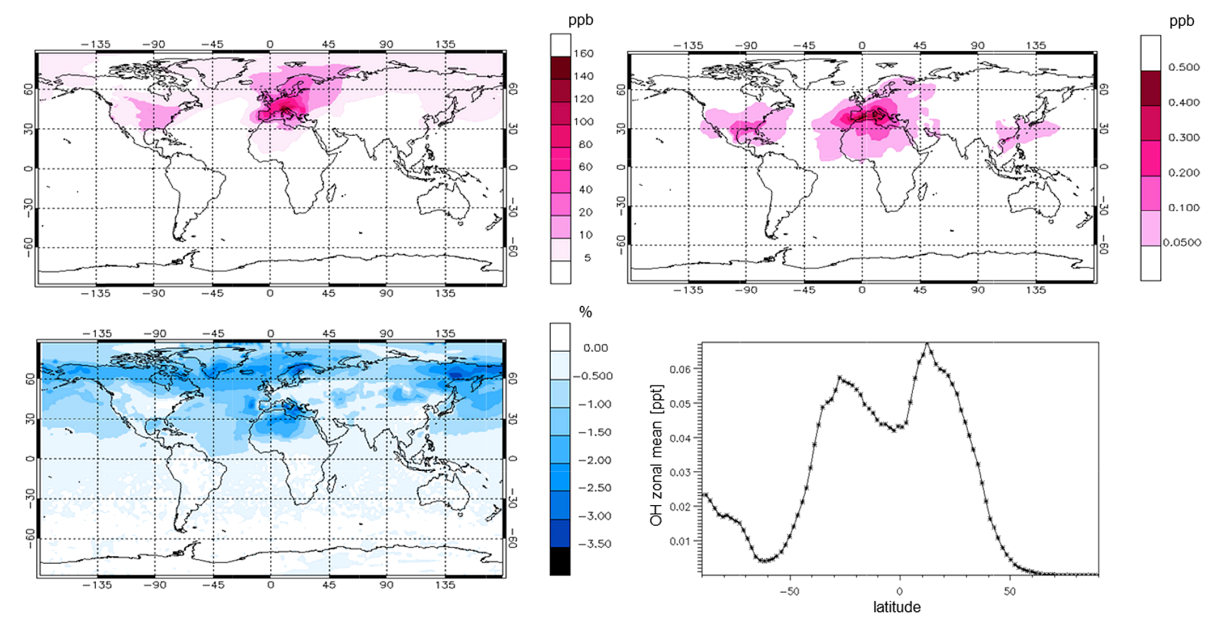

Figure 12. Difference (MI-OPT - MI-DEP) of monthly mean surface level mixing ratios for January 2008. Top panels: CO (left) and ozone (right) absolute bias in parts per billion. Bottom panels: $\mathrm{OH}$ relative bias in percent and absolute MI-DEP zonal mean OH mixing ratios in parts per trillion.

by up to $160 \mathrm{ppb}$ in January. Long-range transport of the additional emissions is confined to the $\mathrm{NH}$, with little effect on Asia and the Pacific.

The regionally scaled emissions have only a small impact on the simulated near-surface ozone mixing ratios and on the free-tropospheric $\mathrm{OH}$ fields. Surface ozone increases almost globally, but nowhere more than $0.5 \mathrm{ppb}$ (Fig. 12, top right panel). This change is smaller than the model bias usually found when MACC results are evaluated with ozone observations (Inness et al., 2013). The $\mathrm{OH}$ radical surface mixing ratios are also evaluated in Fig. 12. As expected, $\mathrm{OH}$ is reduced in the simulation with scaled MACCity emissions due to the increased sink term by CO oxidation. Differences are up to $3 \%$ in the midlatitudes during winter (bottom left panel), where $\mathrm{OH}$ mixing ratios are very small (bottom right panel).

We assess the global annual mean $\mathrm{OH}$ concentration in the MOZART model, as this would influence the $\mathrm{CO}$ budget both for the source term via the chemical conversion of hydrocarbons and for the chemical loss term. $\mathrm{OH}$ in the model cannot be evaluated directly, as atmospheric measurements are lacking. A widely used measure for the integrated tropospheric $\mathrm{OH}$ concentrations is the methane lifetime $\tau\left[\mathrm{CH}_{4}\right]$. In this study, the methane lifetime is $9.7 \mathrm{yr}$ for the MI simulation and $9.8 \mathrm{yr}$ for our simulation MI-OPT. These values are both very close to the mean lifetime calculated from the models in Shindell et al. (2006) $\left(\tau\left[\mathrm{CH}_{4}\right]=9.72 \mathrm{yr}(6.91-12.38)\right)$ as well as in Voulgarakis et al. (2013) $\left(\tau\left[\mathrm{CH}_{4}\right]=9.7 \mathrm{yr}( \pm 0.6)\right)$. As already pointed out by Naik et al. (2013), our modelled methane lifetime suggests that the mean $\mathrm{OH}$ concentration is overestimated by 5 to $10 \%$ but is within the range of uncertainties of observational evidence. From the evaluation with MOPITT and IASI total columns and MOZAIC profiles however, a prevalent underestimation of free-tropospheric model CO concentrations could be deduced. If and how such an underestimation is connected to unrealistic $\mathrm{OH}$ distributions or vertical exchange processes in the model cannot be addressed further without additional observational constraints. Modifications to the chemistry mechanism, which are able to affect global $\mathrm{OH}$ and its spatial distribution, such as proposed by Mao et al. (2013), could also result in higher $\mathrm{CO}$ concentrations. However, this is not yet well established, as there are large uncertainties related to the magnitude of proposed reaction pathways. Therefore these changes are not considered here.

Finally, the global $\mathrm{CO}$ burden calculated from our basic simulation MI is $351 \mathrm{Tg}$, which is slightly lower than the range of the few estimated values for the 1990s (360-470 Tg; see Sect. 1). For MI-OPT the burden increased to $369 \mathrm{Tg}$. Out of this $18 \mathrm{Tg}$ increase, $14 \mathrm{Tg}$ can be appointed to the reduced dry deposition fluxes in the Sanderson scheme. Also the interannual variability of the $\mathrm{CO}$ burden has been calculated with a similar range (Duncan and Logan, 2008).

\section{Conclusions}

The uncertainties in the global budget of $\mathrm{CO}$ have been assessed to explain causes of the long-standing issue of northern hemispheric wintertime underestimation of $\mathrm{CO}$ concentrations in global chemistry transport models. With a series of MOZART sensitivity simulations for the year 2008, the impacts from changing a variety of surface sources and sinks were analysed.

Our basic simulation employed the global emission inventories MACCity, GFASv0, and MEGANv2. Surface CO mixing ratios as measured by GAW stations averaged over the NH were underestimated by more than $20 \mathrm{ppb}$ from December to April, with a maximal bias of $40 \mathrm{ppb}$ in January 
from this simulation. The bias was strongest for the European region ( $75 \mathrm{ppb}$ in January) but also apparent over North America, suggesting that wintertime emissions for these regions are missing in the inventories. Modelled mixing ratios over East Asia were in better agreement with the surface observations, probably reflecting the efforts which were made to update the $\mathrm{CO}$ emissions to the recent economic developments, namely in China. Negative biases were also found for total CO columns when evaluated against MOPITT and IASI observational data. Our comparison showed significantly lower NH modelled columns for almost the whole year. MOPITT and IASI products themselves differed by up to $9 \%$ averaged over the $\mathrm{NH}$, so a quantification of the total column model bias remains uncertain. As pointed out by Worden et al. (2013), the spread in CO column values across the satellite instruments is partly due to spatial sampling differences. The use of different a priori assumptions in the retrieval algorithms also induces differences. The modelled CO was additionally evaluated with MOZAIC profiles over several airports in Europe and North America. Tropospheric CO mixing ratios were mostly underestimated from the model with largest biases for NH winter near the surface.

Four sensitivity simulations, defined by doubling one of the original $\mathrm{CO}$ sources, helped us to identify major sectors which could lead to the underestimation of CO. Doubling the global anthropogenic $\mathrm{CO}$ emissions increased the concentrations all year round but predominately during $\mathrm{NH}$ wintertime. Mixing ratios and total columns simulated with this extreme scenario were always too high as compared with the surface observations and also for regions where the bias of the original simulation was already small. A sensitivity study accounting for missing anthropogenic VOC emissions showed that, although these indirect emissions contribute only about $8 \%$ to the $\mathrm{CO}$ sources, their relative impact is higher in winter, when biogenic emissions are low. Doubling these emissions increased NH wintertime near-surface mixing ratios by 5 to $15 \mathrm{ppb}$ on the global and regional scale; hence biases in anthropogenic VOC emissions can account for a part of the missing model CO. A simulation with doubled biogenic emissions, both from $\mathrm{CO}$ and the VOCs, led to unrealistically high concentrations during boreal summer and early autumn, while $\mathrm{SH}$ tropospheric $\mathrm{CO}$ was greatly overestimated. Similarly, doubling the direct CO emissions from biomass burning led to $\mathrm{CO}$ overestimation peaks during the major $\mathrm{NH}$ wildfire seasons in late spring and summer, hence also excluding biomass burning as the major contributor to the wintertime NH CO bias.

The influence of the dry deposition sink on the global CO budget has been neglected so far by most of the studies on model intercomparison and source inversion. Although this sink is small compared with the photochemical sink on the global, annual average, it becomes more important over the continents and during the winter months, when $\mathrm{OH}$ concentrations are low. A sensitivity simulation with a modified $\mathrm{CO}$ deposition scheme following Sanderson et al. (2003) reduced the global $\mathrm{CO}$ sink by $68 \mathrm{Tg} \mathrm{yr}^{-1}$, with strongest reductions over Europe in wintertime. The resulting $\mathrm{NH}$ surface $\mathrm{CO}$ mixing ratios were enhanced by $20-30 \mathrm{ppb}$ in winter and by $10-15 \mathrm{ppb}$ in summer, with the largest increase over wintertime Europe. Nevertheless, the reduced dry deposition alone was not able to explain the total $\mathrm{CO}$ bias.

A simulation which optimally reflects the surface observations was constructed through application of the modified dry deposition together with a seasonally dependent scaling of CO traffic emissions for Europe and North America only. With this simulation we tested for a possible underestimation of $\mathrm{CO}$ emissions from the traffic sector in the industrialized countries, which could originate from vehicle engines under cold-start conditions. While the resulting surface mixing ratios were very close to the global station observations, a considerable improvement was also reached in comparison with satellite observations and MOZAIC profiles.

Our optimization approach illustrates that regionally missing anthropogenic emissions together with modifications in the dry deposition parameterization could explain the observed biases with respect to American and European GAW station observations. Total CO column densities and tropospheric profiles of $\mathrm{CO}$ mixing ratios were also improved. The optimization approach goes some way in addressing the underestimation of the $\mathrm{CO}$ mixing ratios evident at the MOZAIC airports. The remaining biases point to some model deficiencies in vertical exchange or the $\mathrm{OH}$ distribution and may also be due to the coarse resolution of the model being unable to represent strong local sources of pollution at the airport locations. The strong seasonality in the emission scaling factors used for MI-OPT and its regional differences (Table 4) indicate that a more detailed approach is needed to account for the seasonality in global emission inventories, particularly for emissions of anthropogenic origin.

In conclusion, our simulations have shown that the mismatch between observed and modelled concentrations of $\mathrm{CO}$ during NH wintertime can be explained by a combination of errors in the dry deposition parameterization and the following limitations in the emission inventories: (i) missing anthropogenic $\mathrm{CO}$ emissions from traffic or other combustion processes, (ii) missing anthropogenic VOC emissions, (iii) a poorly established seasonality in the emissions and (iv) a toooptimistic emission reduction in the RCP8.5 scenario underlying the MACCity inventory. There is no indication that our results were greatly influenced by unrealistic global $\mathrm{OH}$ levels, but modelled CO concentrations depend on the modelled $\mathrm{OH}$ distributions, which are themselves subject to limitations in the chemical mechanisms and the lack of knowledge on seasonality and global patterns of $\mathrm{OH}$.

Taking into account that other recently developed global and regional anthropogenic emission inventories (EDGARv4.2, EMEP, EPA) estimate similar low CO emissions for Europe and North America, it remains necessary to question the inventory building process, particularly for the important traffic sector. Furthermore, research efforts are also 
needed to improve the estimates for the seasonal variability of anthropogenic emissions. Finally, in future model studies on the inversion of atmospheric CO observations, the dry deposition parameterization and its global sink term should be more explicitly documented.

Acknowledgements. This study was funded by the European Commission under the Seventh Framework Programme (contract number 218793). Data from the emission inventories used in this study are freely available on the GEIA emission data portal: http://eccad.sedoo.fr/. IASI has been developed and built under the responsibility of the Centre National d'Etudes Spatiales (CNES, France). We are grateful to Pierre Coheur and Daniel Hurtmans (ULB) for developing the FORLI-CO IASI processing code and to Juliette Hadji-Lazaro (LATMOS) for establishing the IASI MACC near-real-time processing chain. The authors acknowledge the strong support of the European Commission, Airbus, and the airlines (Lufthansa, Air France, Austrian, Air Namibia, Cathay Pacific and China Airlines), who carry the MOZAIC or IAGOS equipment and have performed the maintenance since 1994. MOZAIC is presently funded by INSU-CNRS (France), MétéoFrance, CNES, Université Paul Sabatier (Toulouse, France) and Research Center Jülich (FZJ, Jülich, Germany). IAGOS has been, and is additionally, funded by the EU projects IAGOS-DS and IAGOS-ERI. The MOZAIC-IAGOS data are available via the CNES/CNRS-INSU Ether website: http://www.pole-ether.fr. ECMWF and Forschungszentrum Jülich are acknowledged for providing supercomputer time, and we thank Claire Granier and Hugo Denier van der Gon for helpful discussions.

The service charges for this open access publication have been covered by a Research Centre of the Helmholtz Association.

Edited by: V.-H. Peuch

\section{References}

Amann, M., Bertok, I., Cofala, J., Gyarfas, F., Heyes, C., Klimont, Z., Schöpp, W., and Winiwarter, W.: Baseline Scenarios for the Clean Air for Europe (CAFE) Programme, Contract No B43040/2002/340248/MAR/C1, 2005.

Arellano Jr., A. F., Kasibhatla, P. S., Giglio, L., van der Werf, G. R., and Randerson, J. T.: Correction to "Top-down estimates of global CO sources using MOPITT measurements", Geophys. Res. Lett., 31, L12108, doi:10.1029/2004GL020311, 2004.

Arellano Jr., A. F., Kasibhatla, P.- S., Giglio, L., van der Werf, G. R., Randerson, J. T., and Collatz, G. J.: Time-dependent inversion estimates of global biomass-burning CO emissions using Measurement of Pollution in the Troposphere (MOPITT) measurements, J. Geophys. Res., 111, D09303, doi:10.1029/2005JD006613, 2006.

Bergamaschi, P., Hein, R., Heimann, M., and Crutzen, P. J.: Inverse modeling of the global $\mathrm{CO}$ cycle: 1 . Inversion of $\mathrm{CO}$ mixing ratios, J. Geophys. Res., 105, 1909-1927, 2000.

Castellanos, P., Marufu, L. T., Doddridge, B. G., Taubman, B. F., Schwab, J. J., Hains, J. C., Ehrman, S. H., and Dickerson, R.
R.: Ozone, oxides of nitrogen, and carbon monoxide during pollution events over the eastern United States: An evaluation of emissions and vertical mixing, J. Geophys. Res., 116, D16307, doi:10.1029/2010JD014540, 2011.

Clerbaux, C., Boynard, A., Clarisse, L., George, M., Hadji-Lazaro, J., Herbin, H., Hurtmans, D., Pommier, M., Razavi, A., Turquety, S., Wespes, C., and Coheur, P.-F.: Monitoring of atmospheric composition using the thermal infrared IASI/MetOp sounder, Atmos. Chem. Phys., 9, 6041-6054, doi:10.5194/acp-9-6041-2009, 2009.

Conrad, R.: Soil microorganisms as controllers of atmospheric trace gases $\left(\mathrm{H}_{2}, \mathrm{CO}, \mathrm{CH}_{4}, \mathrm{OCS}, \mathrm{N}_{2} \mathrm{O}\right.$, and $\left.\mathrm{NO}\right)$, Microbiol. Rev., 60, 609-640, 1996.

Conrad, R. and Seiler, W.: Influence of temperature, moisture, and organic carbon on the flux of $\mathrm{H}_{2}$ and $\mathrm{CO}$ between soil and atmosphere: field studies in subtropical regions, J. Geophys. Res., 90, 5699-5709, 1985.

Cristofanelli, P., Fierli, F., Marinoni, A., Calzolari, F., Duchi, R., Burkhart, J., Stohl, A., Maione, M., Arduini, J., and Bonasoni, P.: Influence of biomass burning and anthropogenic emissions on ozone, carbon monoxide and black carbon at the Mt. Cimone GAW-WMO global station (Italy, 2165 m a.s.1.), Atmos. Chem. Phys., 13, 15-30, doi:10.5194/acp-13-15-2013, 2013.

Dee, D. P., Uppala, S. M., Simmons, A. J., Berrisford, P., Poli, P., Kobayashi, S., Andrae, U., Balmaseda, M. A., Balsamo, G., Bauer, P., Bechtold, P., Beljaars, A. C. M., van de Berg, L., Bidlot, J., Bormann, N., Delsol, C., Dragani, R., Fuentes, M., Geer, A. J., Haimberger, L., Healy, S. B., Hersbach, H., Hólm, E. V., Isaksen, L., Kållberg, P., Köhler, M., Matricardi, M., McNally, A. P., Monge-Sanz, B. M., Morcrette, J.-J., Park, B.-K., Peubey, C., de Rosnay, P., Tavolato, C., Thépaut, J.-N., and Vitart, F.: The ERA-Interim reanalysis: configuration and performance of the data assimilation system, Q. J. Roy. Meteor. Soc., 137, 553-597, doi:10.1002/qj.828, 2011.

Deeter, M. N., Emmons, L. K., Edwards, D. P., Gille, J. C., and Drummond, J. R.: Vertical resolution and information content of CO profiles retrieved by MOPITT, Geophys. Res. Lett., 31, L15112, doi:10.1029/2004GL020235, 2004.

Deeter, M. N., Worden, H. M., Edwards, D. P., Gille, J. C., Mao, D., and Drummond, J. R.: MOPITT multispectral CO retrievals: Origins and effects of geophysical radiance errors, J. Geophys. Res., 116, D15303, doi:10.1029/2011JD015703, 2011.

Deeter, M. N., Martínez-Alonso, S., Edwards, D. P., Emmons, L. K., Gille, J. C., Worden, H. M., Pittman, J. V., Daube, B. C., and Wofsy, S. C.: Validation of MOPITT Version 5 thermalinfrared, near-infrared, and multispectral carbon monoxide profile retrievals for 2000-2011, J. Geophys. Res. Atmos., 118, 6710-6725, doi:10.1002/jgrd.50272, 2013.

Denier van der Gon, H., Visschedijk, A., van Gijlswijk, R., and Kuenen, J.: High resolution European emission inventory for the years 2003-2007, TNO report, TNO-060-UT-2011-0058: 49, 2011.

Dentener, F., Drevet, J., Lamarque, J. F., Bey, I., Eickhout, B., Fiore, A. M., Hauglustaine, D., Horowitz, L. W., Krol, M., Kulshrestha, U. C., Lawrence, M., Galy-Lacaux, C., Rast, S., Shindell, D., Stevenson, D., Van Noije, T., Atherton, C., Bell, N., Bergman, D., Butler, T., Cofala, J., Collins, B., Doherty, R., Ellingsen, K., Galloway, J., Gauss, M., Montanaro, V., Muller, J. F., Pitari, G., Rodriguez, J., Sanderson, M., Solmon, F., Stra- 
han, S., Schultz, M., Sudo, K., Szopa, S., and Wild, O.: Nitrogen and sulfur deposition on regional and global scales: A multimodel evaluation, Global Biogeochem. Cy., 20, GB4003, doi:10.1029/2005GB002672, 2006.

De Wachter, E., Barret, B., Le Flochmoën, E., Pavelin, E., Matricardi, M., Clerbaux, C., Hadji-Lazaro, J., George, M., Hurtmans, D., Coheur, P.-F., Nedelec, P., and Cammas, J. P.: Retrieval of MetOp-A/IASI CO profiles and validation with MOZAIC data, Atmos. Meas. Tech., 5, 2843-2857, doi:10.5194/amt-5-28432012, 2012.

Drori, R., Dayan, U., Edwards, D. P., Emmons, L. K., and Erlick, C.: Attributing and quantifying carbon monoxide sources affecting the Eastern Mediterranean: a combined satellite, modelling, and synoptic analysis study, Atmos. Chem. Phys., 12, 1067-1082, doi:10.5194/acp-12-1067-2012, 2012.

Drummond, J. R. and Mand, G. S.: The Measurements of Pollution in the Troposphere (MOPITT) Instrument: Overall Performance and Calibration Requirements, J. Atmos. Ocean. Tech., 13, 314 320, 1996

Duncan, B. N. and Bey, I.: A modeling study of the export pathways of pollution from Europe: Seasonal and interannual variations (1987-1997), J. Geophys. Res., 109, D08301, doi:10.1029/2003JD004079, 2004.

Duncan, B. N. and Logan, J. A.: Model analysis of the factors regulating the trends and variability of carbon monoxide between 1988 and 1997, Atmos. Chem. Phys., 8, 7389-7403, doi:10.5194/acp-8-7389-2008, 2008.

Duncan, B. N., Logan, J. A., Bey, I., Megretskaia, I. A., Yantosca, R. M., Novelli, P. C., Jones, N. B., and Rinsland, C. P.: Global budget of CO, 1988-1997: Source estimates and validation with a global model, J. Geophys. Res., 112, D22301, doi:10.1029/2007JD008459, 2007.

EEA, European Union emission inventory report 1990-2011 under the UNECE Convention on Long-range Transboundary Air Pollution (LRTAP), European Environment Agency Copenhagen, Technical Report 10, p. 140, doi:10.2800/44480, 2013.

Ehhalt, D. H. and Rohrer, F.: The tropospheric cycle of H2: a critical review, Tellus B, 61, 500-535, doi:10.1111/j.16000889.2009.00416.x, 2009.

Elguindi, N., Clark, H., Ordóñez, C., Thouret, V., Flemming, J., Stein, O., Huijnen, V., Moinat, P., Inness, A., Peuch, V.-H., Stohl, A., Turquety, S., Athier, G., Cammas, J.-P., and Schultz, M.: Current status of the ability of the GEMS/MACC models to reproduce the tropospheric $\mathrm{CO}$ vertical distribution as measured by MOZAIC, Geosci. Model Dev., 3, 501-518, doi:10.5194/gmd-3501-2010, 2010.

Emmons, L. K., Walters, S., Hess, P. G., Lamarque, J.-F., Pfister, G. G., Fillmore, D., Granier, C., Guenther, A., Kinnison, D., Laepple, T., Orlando, J., Tie, X., Tyndall, G., Wiedinmyer, C., Baughcum, S. L., and Kloster, S.: Description and evaluation of the Model for Ozone and Related chemical Tracers, version 4 (MOZART-4), Geosci. Model Dev., 3, 43-67, doi:10.5194/gmd3-43-2010, 2010.

Eyring, V., Isaksen, I. S. A., Berntsen, T., Collins, W. J., Corbett, J. J., Endresen, O., Grainger, R. G., Moldanova, J., Schlager, H., and Stevenson, D. S.: Transport impacts on atmosphere and climate: Shipping, Atmos. Environ., 44, 4735-4771, doi:10.1016/j.atmosenv.2009.04.059, 2010.
Fisher, J. A., Jacob, D. J., Purdy, M. T., Kopacz, M., Le Sager, P., Carouge, C., Holmes, C. D., Yantosca, R. M., Batchelor, R. L., Strong, K., Diskin, G. S., Fuelberg, H. E., Holloway, J. S., Hyer, E. J., McMillan, W. W., Warner, J., Streets, D. G., Zhang, Q., Wang, Y., and Wu, S.: Source attribution and interannual variability of Arctic pollution in spring constrained by aircraft (ARCTAS, ARCPAC) and satellite (AIRS) observations of carbon monoxide, Atmos. Chem. Phys., 10, 977-996, doi:10.5194/acp10-977-2010, 2010.

Flemming, J., Inness, A., Flentje, H., Huijnen, V., Moinat, P., Schultz, M. G., and Stein, O.: Coupling global chemistry transport models to ECMWF's integrated forecast system, Geosci. Model Dev., 2, 253-265, doi:10.5194/gmd-2-253-2009, 2009.

Fortems-Cheiney, A., Chevallier, F., Pison, I., Bousquet, P., Szopa, S., Deeter, M. N., and Clerbaux, C.: Ten years of $\mathrm{CO}$ emissions as seen from Measurements of Pollution in the Troposphere (MOPITT), J. Geophys. Res., 116, D05304, doi:10.1029/2010JD014416, 2011.

Ganzeveld, L. and Lelieveld, J.: Dry deposition parameterization in a chemistry general circulation model and its influence on the distribution of reactive trace gases, J. Geophys. Res., 100, 20999-21012, 1995.

Ganzeveld, L., Lelieveld, J., and Roelofs, G.-J.: Dry deposition parameterization of sulfur oxides in a chemistry and general circulation model, J. Geophys. Res., 103, 5679-5694, 1998.

Gao, J., Wang, T., Ding, A., and Liu, C.: Observational study of ozone and carbon monoxide at the summit of mount Tai (1534 ma.s.l) in central-eastern China, Atmos. Environ., 39, 4779-4791, 2005.

George, M., Clerbaux, C., Hurtmans, D., Turquety, S., Coheur, P.F., Pommier, M., Hadji-Lazaro, J., Edwards, D. P., Worden, H., Luo, M., Rinsland, C., and McMillan, W.: Carbon monoxide distributions from the IASI/METOP mission: evaluation with other space-borne remote sensors, Atmos. Chem. Phys., 9, 8317-8330, doi:10.5194/acp-9-8317-2009, 2009.

Granier, C., Müller, J.-F., Madronich, S., and Brasseur, G. P.: Possible causes of the 1990-1993 decrease in the global tropospheric CO abundance: A three dimensional sensitivity study, Atmos. Environ., 30, 1673-1682, 1996.

Granier, C., Lamarque, J. F., Mieville, A., Muller, J. F., Olivier, J., Orlando, J., Peters, J., Petron, G., Tyndall, G., and Wallens, S.: POET, a database of surface emissions of ozone precursors, available at http://eccad.sedoo.fr/ (last access: October 2013), 2005.

Granier, C., Bessagnet, B., Bond, T., D'Angiola, A., Denier van der Gon, H., Frost, G. J., Heil, A., Kaiser, J. W., Kinne, S., Klimont, Z., Kloster, S., Lamarque, J.-F., Liousse, C., Masui, T., Meleux, F., Mieville, A., Ohara, R., Raut, J.-C., Riahi, K., Schultz, M G., Smith, S. G., Thompson, A., van Aardenne, J., van der Werf, G. R., and van Vuuren, D. P.: Evolution of anthropogenic and biomass burning emissions of air pollutants at global and regional scales during the 1980-2010 period, Clim. Change, 109, 163-190, doi:10.1007/s10584-011-0154-1, 2011.

Guenther, A., Karl, T., Harley, P., Wiedinmyer, C., Palmer, P. I., and Geron, C.: Estimates of global terrestrial isoprene emissions using MEGAN (Model of Emissions of Gases and Aerosols from Nature), Atmos. Chem. Phys., 6, 3181-3210, doi:10.5194/acp-63181-2006, 2006. 
Hooghiemstra, P. B., Krol, M. C., Meirink, J. F., Bergamaschi, P., van der Werf, G. R., Novelli, P. C., Aben, I., and Röckmann, T.: Optimizing global $\mathrm{CO}$ emission estimates using a four-dimensional variational data assimilation system and surface network observations, Atmos. Chem. Phys., 11, 4705-4723, doi:10.5194/acp-11-4705-2011, 2011.

Hooghiemstra, P. B., Krol, M. C., Bergamaschi, P., de Laat, A. T. J., van der Werf, G. R., Novelli, P. C., Deeter, M. N., Aben, I., and Röckmann, T.: Comparing optimized $\mathrm{CO}$ emission estimates using MOPITT or NOAA surface network observations, J. Geophys. Res., 117, D06309, doi:10.1029/2011JD017043, 2012.

Horowitz, L. W., Walters, S., Mauzerall, D. L., Emmons, L. K., Rasch, P. J., Granier, C., Tie, X., Lamarque, J.-F., Schultz, M. G., Tyndall, G. S., Orlando, J. J., and Brasseur, G. P.: A global simulation of tropospheric ozone and related tracers: Description and evaluation of MOZART, version 2, J. Geophys. Res., 108, 4784, doi:10.1029/2002JD002853, 2003.

Huijnen, V., Williams, J., van Weele, M., van Noije, T., Krol, M., Dentener, F., Segers, A., Houweling, S., Peters, W., de Laat, J., Boersma, F., Bergamaschi, P., van Velthoven, P., Le Sager, P., Eskes, H., Alkemade, F., Scheele, R., Nédélec, P., and Pätz, H.-W.: The global chemistry transport model TM5: description and evaluation of the tropospheric chemistry version 3.0, Geosci. Model Dev., 3, 445-473, doi:10.5194/gmd-3-445-2010, 2010.

Hurtmans, D., Coheur, P.-F., Wespes, C., Clarisse, L., Scharf, O., Clerbaux, C., Hadji-Lazaro, J., George, M., and Turquety, S.: FORLI radiative transfer and retrieval code for IASI. J. Quant. Spectrosc. Radiat. Transfer, 113, 1391-1408, doi:10.1016/j.jqsrt.2012.02.036, 2012.

Inness, A., Baier, F., Benedetti, A., Bouarar, I., Chabrillat, S., Clark, H., Clerbaux, C., Coheur, P., Engelen, R. J., Errera, Q., Flemming, J., George, M., Granier, C., Hadji-Lazaro, J., Huijnen, V., Hurtmans, D., Jones, L., Kaiser, J. W., Kapsomenakis, J., Lefever, K., Leitão, J., Razinger, M., Richter, A., Schultz, M. G., Simmons, A. J., Suttie, M., Stein, O., Thépaut, J.-N., Thouret, V., Vrekoussis, M., Zerefos, C., and the MACC team: The MACC reanalysis: an $8 \mathrm{yr}$ data set of atmospheric composition, Atmos. Chem. Phys., 13, 4073-4109, doi:10.5194/acp-13-4073-2013, 2013.

Janssens-Maenhout, G., Petrescu, A. M. R., Muntean, M., and Blujdea, V.: Verifying Greenhouse Gas Emissions: Methods to Support International Climate Agreements, Greenhouse Gas Measurement and Management, 1, 132-133, doi:10.1080/20430779.2011.579358, 2011.

Kaiser, J. W., Heil, A., Schultz, M. G., Stein, O., van der Werf, G. R., Wooster, M. J., and Xu, W.: Final report on implementation and quality of the D-FIRE assimilation system, MACC deliverable D-FIRE 7, ECMWF, 2011.

Kaiser, J. W., Heil, A., Andreae, M. O., Benedetti, A., Chubarova, N., Jones, L., Morcrette, J.-J., Razinger, M., Schultz, M. G., Suttie, M., and van der Werf, G. R.: Biomass burning emissions estimated with a global fire assimilation system based on o bserved fire radiative power, Biogeosciences, 9, 527-554, doi:10.5194/bg-9-527-2012, 2012.

Kerzenmacher, T., Dils, B., Kumps, N., Blumenstock, T., Clerbaux, C., Coheur, P.-F., Demoulin, P., García, O., George, M., Griffith, D. W. T., Hase, F., Hadji-Lazaro, J., Hurtmans, D., Jones, N., Mahieu, E., Notholt, J., Paton-Walsh, C., Raffalski, U., Ridder, T., Schneider, M., Servais, C., and De Mazière, M.: Validation of
IASI FORLI carbon monoxide retrievals using FTIR data from NDACC, Atmos. Meas. Tech., 5, 2751-2761, doi:10.5194/amt5-2751-2012, 2012.

King, G. M.: Characteristics and significance of atmospheric carbon monoxide consumption by soils, Chemosphere, 1, 53-63, doi:10.1016/S1465-9972(99)00021-5, 1999.

Kinnison, D. E., Brasseur, G. P., Walters, S., Garcia, R. R., Marsh, D. R, Sassi, F., Harvey, V. L., Randall, C. E., Emmons, L., Lamarque, J. F., Hess, P., Orlando, J. J., Tie, X. X., Randel, W., Pan, L. L., Gettelman, A., Granier, C., Diehl, T., Niemeier, U., and Simmons, A. J.: Sensitivity of Chemical Tracers to Meteorological Parameters in the MOZART-3 Chemical Transport Model, J. Geophys. Res, 112, D03303, doi:10.1029/2008JD010739, 2007.

Klemp, D., Mihelcic, D., and Mittermaier, B.: Messung und Bewertung von Verkehrsemissionen (in German), Schriften des Forschungszentrums Jülich, Reihe Energie und Umwelt, Vol. 21, p. 318, ISBN:978-3-89336-546-3, Jülich, 2012.

Kopacz, M., Jacob, D. J., Fisher, J. A., Logan, J. A., Zhang, L., Megretskaia, I. A., Yantosca, R. M., Singh, K., Henze, D. K., Burrows, J. P., Buchwitz, M., Khlystova, I., McMillan, W. W., Gille, J. C., Edwards, D. P., Eldering, A., Thouret, V., and Nedelec, P.: Global estimates of $\mathrm{CO}$ sources with high resolution by adjoint inversion of multiple satellite datasets (MOPITT, AIRS, SCIAMACHY, TES), Atmos. Chem. Phys., 10, 855-876, doi:10.5194/acp-10-855-2010, 2010.

Kurokawa, J., Ohara, T., Morikawa, T., Hanayama, S., JanssensMaenhout, G., Fukui, T., Kawashima, K., and Akimoto, H.: Emissions of air pollutants and greenhouse gases over Asian regions during 2000-2008: Regional Emission inventory in ASia (REAS) version 2, Atmos. Chem. Phys., 13, 11019-11058, doi:10.5194/acp-13-11019-2013, 2013.

Lamarque, J.-F., Bond, T. C., Eyring, V., Granier, C., Heil, A., Klimont, Z., Lee, D., Liousse, C., Mieville, A., Owen, B., Schultz, M. G., Shindell, D., Smith, S. J., Stehfest, E., Van Aardenne, J., Cooper, O. R., Kainuma, M., Mahowald, N., McConnell, J. R., Naik, V., Riahi, K., and van Vuuren, D. P.: Historical (1850-2000) gridded anthropogenic and biomass burning emissions of reactive gases and aerosols: methodology and application, Atmos. Chem. Phys., 10, 7017-7039, doi:10.5194/acp10-7017-2010, 2010.

Lamarque, J.-F., Emmons, L. K., Hess, P. G., Kinnison, D. E., Tilmes, S., Vitt, F., Heald, C. L., Holland, E. A., Lauritzen, P. H., Neu, J., Orlando, J. J., Rasch, P. J., and Tyndall, G. K.: CAM-chem: description and evaluation of interactive atmospheric chemistry in the Community Earth System Model, Geosci. Model Dev., 5, 369-411, doi:10.5194/gmd-5-369-2012, 2012.

Law, K. S. and Stohl, A.: Arctic air pollution: Origins and impacts, Science, 315, 1537-1540, 2007.

Li, Q., Jacob, D. J., Bey, I., Palmer, P. I., Duncan, B. N., Field, B. D., Martin, R. V., Fiore, A. M., Yantosca, R. M., Parrish, D. D., Simmonds, P. G., and Oltmans, S. J.: Transatlantic transport of pollution and its effects on surface ozone in Europe and North America, J. Geophys. Res., 107, 4166, doi:10.1029/2001JD001422, 2002.

Liu, H., Jacob, D. J., Bey, I., Yantosca, R. M., Duncan, B. N., and Sachse, G. W.: Transport pathways for Asian pollution outflow over the Pacific: interannual and seasonal variations, J. Geophys. Res., 108, 8786, doi:10.1029/2002JD003102, 2003. 
Mao, J., Fan, S., Jacob, D. J., and Travis, K. R.: Radical loss in the atmosphere from $\mathrm{Cu}-\mathrm{Fe}$ redox coupling in aerosols, Atmos. Chem. Phys., 13, 509-519, doi:10.5194/acp-13-509-2013, 2013.

Marenco, A., Thouret, V., Nédélec, P., Smit, H., Helten, M., Kley, D., Karcher, F., Simon, P., Law, K., Pyle, J., Poschmann, G., Von Wrede, R., Hume, C., and Cook, T.: Measurement of ozone and water vapour by Airbus in-service aircraft: The MOZAIC airborne program, an overview, J. Geophys. Res., 103, 2563125642, doi:10.1029/98JD00977, 1998.

Miyazaki, K., Eskes, H. J., Sudo, K., Takigawa, M., van Weele, M., and Boersma, K. F.: Simultaneous assimilation of satellite $\mathrm{NO}_{2}$, $\mathrm{O}_{3}, \mathrm{CO}$, and $\mathrm{HNO}_{3}$ data for the analysis of tropospheric chemical composition and emissions, Atmos. Chem. Phys., 12, 95459579, doi:10.5194/acp-12-9545-2012, 2012.

Moss, R. H., Edmonds, J. A., Hibbard, K., Manning, M., Rose, S. K., van Vuuren, D. P., Carter, T. R., Emori, S., Kainuma, M., Kram, T., Meehl, G., Mitchell, J., Nakicenovic, N., Riahi, K., Smith, S. J., Stouffer, R. J., Thomson, A., Weyant, J., and Wilbanks, T.: The Next Generation of Scenarios for Climate Change Research and Assessment, Nature, 463, 747-756, doi:10.1038/nature08823, 2010.

Müller, J.-F. and Stavrakou, T.: Inversion of $\mathrm{CO}$ and $\mathrm{NO}_{\mathrm{x}}$ emissions using the adjoint of the IMAGES model, Atmos. Chem. Phys., 5, 1157-1186, doi:10.5194/acp-5-1157-2005, 2005.

Naik, V., Voulgarakis, A., Fiore, A. M., Horowitz, L. W., Lamarque, J.-F., Lin, M., Prather, M. J., Young, P. J., Bergmann, D., Cameron-Smith, P. J., Cionni, I., Collins, W. J., Dalsøren, S. B., Doherty, R., Eyring, V., Faluvegi, G., Folberth, G. A., Josse, B., Lee, Y. H., MacKenzie, I. A., Nagashima, T., van Noije, T. P. C., Plummer, D. A., Righi, M., Rumbold, S. T., Skeie, R., Shindell, D. T., Stevenson, D. S., Strode, S., Sudo, K., Szopa, S., and Zeng, G.: Preindustrial to present-day changes in tropospheric hydroxyl radical and methane lifetime from the Atmospheric Chemistry and Climate Model Intercomparison Project (ACCMIP), Atmos. Chem. Phys., 13, 5277-5298, doi:10.5194/acp-13-5277-2013, 2013.

Novelli, P. C., Masarie, K. A., and Lang, P. M.: Distributions and recent changes of carbon monoxide in the lower troposphere, J. Geophys. Res., 103, 19015-19033, doi:10.1029/98JD01366, 1998.

Ohara, T., Akimoto, H., Kurokawa, J., Horii, N., Yamaji, K., Yan, X., and Hayasaka, T.: An Asian emission inventory of anthropogenic emission sources for the period 1980-2020, Atmos. Chem. Phys., 7, 4419-4444, doi:10.5194/acp-7-4419-2007, 2007.

Parrish, D. D.: Critical evaluation of U.S. on-road vehicle emission inventories, Atmos. Environ., 40, 2288-2300, 2006.

Pétron, G., Granier, C., Khattatov, B., Lamarque, J., Yudin, V., Müller, J., and Gille, J.: Inverse modeling of carbon monoxide surface emissions using Climate Monitoring and Diagnostics Laboratory network observations, J. Geophys. Res., 107, 4761, doi:10.1029/2001JD001305, 2002.

Pétron, G., Granier, C., Khattatov, B., Yudin, V, Lamarque, J.-F., Emmons, L., Gille, J., and Edwards, D. P.: Monthly CO surface sources inventory based on the 2000-2001 MOPITT satellite data, Geophys. Res. Lett., 31, L21107, doi:10.1029/2004GL020560, 2004.

Pfister, G., Emmons, L. K., Hess, P. G., Lamarque, J.-F., Walters, S., Guenther, A., Palmer, P. I., and Lawrence, P.: Contribu- tion of isoprene to chemical budgets: A model tracer study with the NCAR CTM MOZART-4, J. Geophys. Res., 113, D05308, doi:10.1029/2007JD008948, 2008.

Pison, I., Bousquet, P., Chevallier, F., Szopa, S., and Hauglustaine, D.: Multi-species inversion of $\mathrm{CH}_{4}, \mathrm{CO}$ and $\mathrm{H}_{2}$ emissions from surface measurements, Atmos. Chem. Phys., 9, 5281-5297, doi:10.5194/acp-9-5281-2009, 2009.

Pouliot, G., Pierce, T. E., Denier van der Gon, H., Schaap, M., Moran, M., and Nopmongeol, U.: Comparing Emission Inventories and Model-Ready Emission Datasets between Europe and North America for the AQMEII Project, Atmos. Environ., 53, 414, 2012.

Prather, M., Ehhalt, D., Dentener, F., Derwent, R. G., Dlugokencky, E., Holland, E., Isaksen, I. S. A., Katima, J., Kirchhoff, V., Matson, P., Midgley, P. M., and Wang, M.: Atmospheric chemistry and greenhouse gases, in: Climate Change 2001, edited by: Houghton, J. T., 239-287, Cambridge Univ. Press, New York, 2001.

Prather, M. J., Holmes, C. D., and Hsu, J.: Reactive greenhouse gas scenarios: Systematic exploration of uncertainties and the role of atmospheric chemistry, Geophys. Res. Lett., 39, L09803, doi:10.1029/2012GL051440, 2012.

Price, C., Penner, J., and Prather, M.: $\mathrm{NO}_{\mathrm{x}}$ from lightning 1, Global distribution based on lightning physics, J. Geophys. Res., 102, 5929-5941, 1997.

Prinn, R. G., Huang, J., Weiss, R. F., Cunnold, D. M., Fraser, P. J., Simmonds, P. G., McCulloch, A., Harth, C., Reimann, S., Salameh, P., O’Doherty, S., Wang, R. H. J., Porter, L. W., Miller, B. R., and Krummel, P. B.: Evidence for variability of atmospheric hydroxyl radicals over the past quarter century, Geophys Res. Lett., 32, L07809, doi:10.1029/2004GL022228, 2005.

Reichle, H. G. and Connors, V. S.: The Mass of CO in the Atmosphere during October 1984, April 1994, and October 1994, J. Atmos. Sci., 56, 307-310, 1999.

Riahi K., Rao, S., Krey, V., Cho, C., Chirkov, V., Fischer, G., Kindermann, G., Nakicenovic, N.,and Rafaj, P.: RCP 8.5 - A scenario of comparatively high greenhouse gas emissions, Climatic Change, 109, 33-57, doi:10.1007/s10584-011-0149-y, 2011.

Richter, C. and Schultz, M. G.: Impact of emission changes on climate, in: CITYZEN Climate Impact Studies, edited by: Schultz, M. G., Schriften des Forschungszentrums Jülich, Reihe Energie \& Umwelt/Energy \& Environment, 116, ISBN:978-3-89336729-0, 17-38, Jülich, 2011.

Rodgers, C. D.: Inverse Methods for Atmospheric Sounding, Theory and Practice, World Scientific, Singapore, p. 256, 2000.

Sander, S. P., Finlayson-Pitts, B. J., Friedl, R. R., Golden, D. M., Huie, R. E., Keller-Rudek, H., Kolb, C. E., Kurylo, M. J., Molina, M. J., Moortgat, G. K., Orkin, V. L., Ravishankara, A. R., and Wine, P. W.: Chemical Kinetics and Photochemical Data for Use in Atmospheric Studies, Evaluation Number 15, JPL Publication 06-02, Jet Propulsion Laboratory, Pasadena, Calif., 2006.

Sanderson, M. G., Collins, W. J., Derwent, R. G., and Johnson, C. E.: Simulation of global hydrogen levels using a Lagrangian three-dimensional model, J. Atmos. Chem., 46, 15-28, 2003.

Sanhueza, E., Dong, Y., Scharffe, D., Lobert, J. M., and Crutzen, P. J.: Carbon monoxide uptake by temperate forest soils: the effects of leaves and humus layers, Tellus B, 50, 51-58, doi:10.1034/j.1600-0889.1998.00004.x, 1998. 
Schultz, M. G., Backman, L., Balkanski, Y., Bjoerndalsaeter, S., Brand, R., Burrows, J. P., Dalsoeren, S., de Vasconcelos, M., Grodtmann, B., Hauglustaine, D. A., Heil, A., Hoelzemann, J. J., Isaksen, I. S. A., Kaurola, J., Knorr, W., LadstaetterWeißenmayer, A., Mota, B., Oom, D., Pacyna, J., Panasiuk, D., Pereira, J. M. C., Pulles, T., Pyle, J., Rast, S., Richter, A., Savage, N., Schnadt, C., Schulz, M., Spessa, A., Staehelin, J., Sundet, J. K., Szopa, S., Thonicke, K., van het Bolscher, M., van Noije, T., van Velthoven, P., Vik, A. F., and Wittrock, F.: Reanalysis of the tropospheric chemical composition over the past 40 years (RETRO) - A long-term global modeling study of tropospheric chemistry, Reports on Earth System Science, 48/2007, Max Planck Institute for Meteorology, Hamburg, ISSN:16141199, p. 122, 2007.

Shindell, D. T., Faluvegi, G., Stevenson, D. S., Krol, M. C., Emmons, L. K., Lamarque, J.-F., Petron, G., Dentener, F. J., Ellingsen, K., Schultz, M. G., Wild, O., Amann, M., Atherton, C. S., Bergmann, D. J., Bey, I., Butler, T., Cofala, J., Collins, W. J., Derwent, R. G., Doherty, R. M., Drevet, J., Eskes, H. J., Fiore, A. M., Gauss, M., Hauglustaine, D. A., Horowitz, L.W., Isaksen, I. S. A., Lawrence, M. G., Montanaro, V., Muller, J. F., Pitari, G., Prather, M. J., Pyle, J. A., Rast, S., Rodriguez, J. M., Sanderson, M. G., Savage, N. H., Strahan, S. E., Sudo, K., Szopa, S., Unger, N., van Noije, T. P. C., and Zeng, G.: Multimodel simulations of carbon monoxide: Comparison with observations and projected near-future changes, J. Geophys. Res., 111, D19306, doi:10.1029/2006JD007100, 2006.

Shindell, D. T., Chin, M., Dentener, F., Doherty, R. M., Faluvegi, G., Fiore, A. M., Hess, P., Koch, D. M., MacKenzie, I. A., Sanderson, M. G., Schultz, M. G., Schulz, M., Stevenson, D. S., Teich, H., Textor, C., Wild, O., Bergmann, D. J., Bey, I., Bian, H., Cuvelier, C., Duncan, B. N., Folberth, G., Horowitz, L. W., Jonson, J., Kaminski, J. W., Marmer, E., Park, R., Pringle, K. J., Schroeder, S., Szopa, S., Takemura, T., Zeng, G., Keating, T. J., and Zuber, A.: A multi-model assessment of pollution transport to the Arctic, Atmos. Chem. Phys., 8, 5353-5372, doi:10.5194/acp-85353-2008, 2008.

Sindelarova, K., Granier, C., Bouarar, I., Guenther, A., Tilmes, S., Stavrakou, T., Müller, J.-F., Kuhn, U., Stefani, P., and Knorr, W.: Global dataset of biogenic VOC emissions calculated by the MEGAN model over the last 30 years, Atmos. Chem. Phys. Discuss., 14, 10725-10788, doi:10.5194/acpd-14-10725-2014, 2014.

Stein, O., Flemming, J., Inness, A., Kaiser, J. W., and Schultz, M. G.: Global reactive gases and reanalysis in the MACC project, Journal of Integrative Environmental Sciences, 9, Iss. sup1, 5770, doi:10.1080/1943815X.2012.696545, 2012.

Stevenson, D. S.: Multimodel ensemble simulations of presentday and near-future tropospheric ozone, J. Geophys. Res., 111, D08301, doi:10.1029/2005JD006338, 2006.

van der Werf, G. R., Randerson, J. T., Giglio, L., Collatz, G. J., Kasibhatla, P. S., and Arellano Jr., A. F.: Interannual variability in global biomass burning emissions from 1997 to 2004, Atmos. Chem. Phys., 6, 3423-3441, doi:10.5194/acp-6-3423-2006, 2006. van der Werf, G. R., Randerson, J. T., Giglio, L., Collatz, G. J., Mu, M., Kasibhatla, P. S., Morton, D. C., DeFries, R. S., Jin, Y., and van Leeuwen, T. T.: Global fire emissions and the contribution of deforestation, savanna, forest, agricultural, and peat fires (19972009), Atmos. Chem. Phys., 10, 11707-11735, doi:10.5194/acp10-11707-2010, 2010.

van Vuuren, D. P., Edmonds, J., Kainuma, M., Riahi, K., Thomson, A. Hibbard, K., Hurtt, G. C., Kram, T., Krey, V., Lamarque, J.F., Masui, T., Meinshausen, M., Nakicenovic, N., Smith, S. J., and Rose, S. K.: The representative concentration pathways: an overview, Climatic Change, 109, 5-31, doi:10.1007/s10584-0110148-z, 2011.

Voulgarakis, A., Naik, V., Lamarque, J.-F., Shindell, D. T., Young, P. J., Prather, M. J., Wild, O., Field, R. D., Bergmann, D., CameronSmith, P., Cionni, I., Collins, W. J., Dalsøren, S. B., Doherty, R. M., Eyring, V., Faluvegi, G., Folberth, G. A., Horowitz, L. W., Josse, B., MacKenzie, I. A., Nagashima, T., Plummer, D. A., Righi, M., Rumbold, S. T., Stevenson, D. S., Strode, S. A., Sudo, K., Szopa, S., and Zeng, G.: Analysis of present day and future $\mathrm{OH}$ and methane lifetime in the ACCMIP simulations, Atmos. Chem. Phys., 13, 2563-2587, doi:10.5194/acp-13-25632013, 2013.

Wang, Y. X., McElroy, M. B., Wang, T., and Palmer, P. I.: Asian emissions of $\mathrm{CO}$ and $\mathrm{NO}_{\mathrm{x}}$ : Constraints from aircraft and Chinese station data, J. Geophys. Res., 109, D24304, doi:10.1029/2004JD005250, 2004.

Wesely, M. L.: Parameterization of surface resistance to gaseous dry deposition in regional-scale numerical models, Atmos. Environ., 23, 1293-1304, 1989.

Wesely, M. L. and Hicks, B. B.: A review of the current status of knowledge in dry deposition, Atmos. Environ., 34, 2261-2282, 2000.

Williams, J. E., van Velthoven, P. F. J., and Brenninkmeijer, C. A. M.: Quantifying the uncertainty in simulating global tropospheric composition due to the variability in global emission estimates of Biogenic Volatile Organic Compounds, Atmos. Chem. Phys., 13, 2857-2891, doi:10.5194/acp-13-2857-2013, 2013.

Worden, H. M., Deeter, M. N., Edwards, D. P., Gille, J. C., Drummond, J. R., and Nédélec, P. P.: Observations of near-surface carbon monoxide from space using MOPITT multispectral retrievals, J. Geophys. Res., 115, D18314, doi:10.1029/2010JD014242, 2010.

Worden, H. M., Deeter, M. N., Frankenberg, C., George, M., Nichitiu, F., Worden, J., Aben, I., Bowman, K. W., Clerbaux, C., Coheur, P. F., de Laat, A. T. J., Detweiler, R., Drummond, J. R., Edwards, D. P., Gille, J. C., Hurtmans, D., Luo, M., MartínezAlonso, S., Massie, S., Pfister, G., and Warner, J. X.: Decadal record of satellite carbon monoxide observations, Atmos. Chem. Phys., 13, 837-850, doi:10.5194/acp-13-837-2013, 2013.

Yonemura, S., Kawashima, S., and Tsuruta, H.: Carbon monoxide, hydrogen, and methane uptake by soils in a temperate arable field and a forest, J. Geophys. Res., 105, 14347-14362, 2000. 